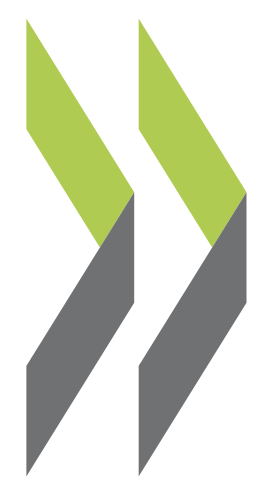

OECD Science, Technology and Industry Working Papers $2012 / 03$

International Comparative Evidence on Global Value Chains
Koen De Backer, Norihiko Yamano 


\section{Unclassified}

DSTI/DOC(2012)3

Organisation de Coopération et de Développement Économiques

Organisation for Economic Co-operation and Development

23-Apr-2012

DIRECTORATE FOR SCIENCE, TECHNOLOGY AND INDUSTRY

English - Or. English

\section{INTERNATIONAL COMPARATIVE EVIDENCE ON GLOBAL VALUE CHAINS}

OECD Science, Technology and Industry Working Paper 2012/3

By Koen de Backer and Norihiko Yamano (OECD)

Complete document available on OLIS in its original format

This document and any map included herein are without prejudice to the status of or sovereignty over any territory, to the delimitation of international frontiers and boundaries and to the name of any territory, city or area. 


\section{STI Working Paper Series}

The Working Paper series of the OECD Directorate for Science, Technology and Industry is designed to make available to a wider readership selected studies prepared by staff in the Directorate or by outside consultants working on OECD projects. The papers included in the series cover a broad range of issues, of both a technical and policy-analytical nature, in the areas of work of the DSTI. The Working Papers are generally available only in their original language - English or French - with a summary in the other.

Comments on the papers are invited, and should be sent to the Directorate for Science, Technology and Industry, OECD, 2 rue André-Pascal, 75775 Paris Cedex 16, France.

The opinions expressed in these papers are the sole responsibility of the author(s) and do not necessarily reflect those of the OECD or of the governments of its member countries.

\section{www.oecd.org/sti/working-papers}

OECD/OCDE, 2011

Applications for permission to reproduce or translate all or part of this material should be made to: OECD Publications, 2 rue André-Pascal, 75775 Paris, Cedex 16, France; e-mail: rights@oecd.org 
DSTI/DOC(2012)3

\title{
INTERNATIONAL COMPARATIVE EVIDENCE ON GLOBAL VALUE CHAINS
}

\author{
Koen De Backer and Norihiko Yamano ${ }^{1}$
}

\begin{abstract}
The past decades have witnessed a rapid globalisation of economic activity which has significantly changed the outlook of the world economy. International production, trade and investments are increasingly organised within so-called global value chains (GVCs) where the different stages in the production process are located across different economies. Until now, GVCs have been largely discussed from a conceptual and theoretical view, but empirical work on international fragmentation has stayed a bit behind.

The review of the available data and indicators on GVCs in this paper shows the increasing importance of GVCs in today's global economy, but at the same time clearly highlights some major shortcomings. While the empirical evidence based on trade data is less convincing, Input-Output data clearly reveal the growing spread of international production networks. Indicators on imported intermediates, offshoring and vertical specialisation all illustrate the growing fragmentation of production across more economies. Trade data seem to show the increasing importance of GVCs only in an indirect way but the existing trade data are not detailed enough and are not collected on the right level of analysis to analyse the international fragmentation and GVCs.

Policy makers show an increasing interest in GVCs because of the pervasive effects GVCs have on national economies and are especially looking for more and better policy evidence. Important policy issues like the impact of GVCs on the competitiveness of countries and attractiveness for international investments can only be addressed by new and better metrics. The OECD is developing new empirical evidence studying the emergence of GVCs based on international trade data and Input-Output data. In addition, the OECD is currently cooperating with other international agencies and academic experts to develop new metrics for GVCs, for example data on trade in value added.
\end{abstract}

Koen De Backer is Senior Economist in the Structural Policy Division and Norihiko Yamano is Policy Analyst in the Economic Analysis and Statistics Division of the OECD STI Directorate. 


\title{
DONNÉES FACTUELLES INTERNATIONALES COMPARABLES SUR LES CHAÎNES DE VALEUR MONDIALES
}

\author{
Koen De Backer et Norihiko Yamano ${ }^{2}$
}

\begin{abstract}
Résumé
Depuis quelques décennies, l'activité économique planétaire connait une mondialisation rapide, qui transforme profondément le paysage de l'économie mondiale. La production, les échanges et l'investissement internationaux s'organisent de plus en plus en chaînes de valeur mondiales (CVM) dans lesquelles les différents segments des processus de production sont répartis sur plusieurs territoires. Jusqu'à présent, les CVM ont principalement été étudiées d'un point de vue conceptuel et théorique, les travaux empiriques sur la segmentation internationale ayant été quelque peu délaissés.

L'examen des données et indicateurs disponibles sur les CVM dans cette étude met en évidence l'importance accrue des CVM dans l'économie mondiale, tout en faisant clairement apparaître d'importants manques. Si les éléments empiriques reposant sur les chiffres des échanges sont peu convaincants, les données d'entrées-sorties montrent clairement l'extension grandissante des réseaux internationaux de production. Les indicateurs sur les importations de produits intermédiaires, sur les délocalisations et sur la spécialisation verticale illustrent tous la segmentation croissante de la production entre un plus grand nombre d'économies. Les données sur les échanges semblent montrer l'importance croissante des CVM, d'une manière indirecte, et celles dont on dispose ne sont pas suffisamment détaillées et ne sont pas collectées à un niveau d'analyse qui conviendrait pour analyser la segmentation internationale et les CVM.

Les responsables politiques manifestent un intérêt croissant pour les CVM en raison de leurs effets profonds sur les économies nationales, et ils ont particulièrement besoin de données plus exhaustives et de meilleure qualité. Certains enjeux importants pour les politiques, tels que l'impact des CVM sur la compétitivité des pays et leur attractivité pour l'investissement international, ne peuvent être abordés qu'à l'aide de mesures nouvelles et de meilleure qualité. L'OCDE produit de nouveaux éléments empiriques pour étudier l'émergence des CVM à partir des données sur les échanges internationaux et les entrées-sorties. Par ailleurs, l'OCDE coopère actuellement avec d'autres instances internationales et avec des experts universitaires à la construction de nouvelles mesures pour les CVM, par exemple de données sur les échanges en valeur ajoutée.
\end{abstract}

$2 \quad$ Koen De Backer est Économiste principal à la Division de la politique structurelle et Norihiko Yamano est analyste des politiques à la Division des analyses économiques et des statistiques de la DSTI de l'OCDE. 


\section{TABLE OF CONTENTS}

INTERNATIONAL COMPARATIVE EVIDENCE ON GLOBAL VALUE CHAINS .............................. 3 DONNÉES FACTUELLES INTERNATIONALES COMPARABLES SUR LES CHAÎNES DE

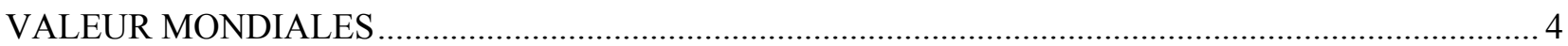

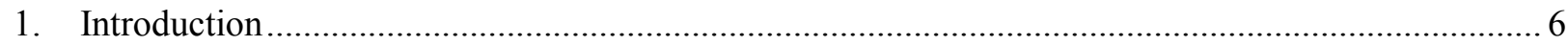

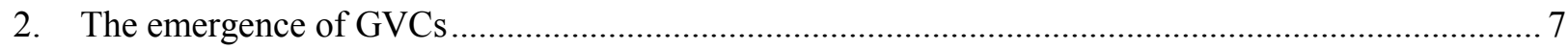

3. Are there any stylised facts on GVCs based on trade data? ............................................................ 8

4. Input-Output data confirm the increasing importance of GVCs ................................................... 12

5. Economic linkages between countries: linking IO data with trade data ....................................... 22

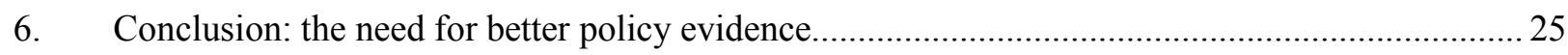

ANNEX 1. DOMINANT LINKS BETWEEN ECONOMIES, EXPORTS OF INTERMEDIATES, 199527

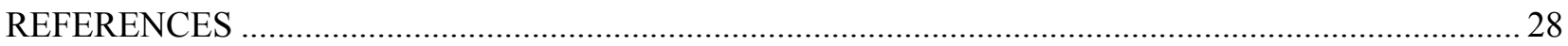




\section{INTERNATIONAL COMPARATIVE EVIDENCE ON GLOBAL VALUE CHAINS}

\section{Introduction}

The past decades have witnessed a rapid globalisation of economic activity which has significantly changed the outlook of the world economy. An increasing number of firms, countries and other economic actors take part in today's global economy and have become increasingly connected across borders. International production, trade and investments are increasingly organised within so-called global value chains (GVCs) where the different stages in the production process are located across different economies. Intermediate inputs like parts and components are produced in one country and then exported to other countries for further production and/or assembly in final products.

This functional and spatial fragmentation within GVCs is significantly affecting how the global economy operates and has increased the economic interdependency between economies. The increasing importance of intermediates clearly suggests that economies no longer rely only on domestic resources to produce goods and services and export these to the rest of world (Sturgeon and Gereffi, 2009). Countries just like firms increasingly become specialised in specific functions within these GVCs.

The spatial distribution of corporate activities within GVCs has been facilitated by the strong decline in transportation and communication costs (Grossman and Rossi-Hansberg, 2006; Baldwin, 2006). In addition, rapid technological advances in ICT have dramatically decreased the cost of organising and coordinating complex activities over (long) distances. Plummeting costs of processing and transmitting information, organisational innovations and the development of international standards for products descriptions and business protocols have further facilitated the spread of GVCs.

While GVCs have been largely discussed from a conceptual and theoretical view, empirical work on international fragmentation has stayed a bit behind. The existing evidence is mainly restricted to case study work (e.g. the Barbie doll and the Apple iPod) and industry-specific surveys, but does not depict a more comprehensive picture of the integrated global productions structure. The OECD has recently developed new empirical evidence studying the emergence of GVCs primarily based on harmonised international trade data and Input-Output data. ${ }^{3}$

By reviewing the internationally comparable evidence, this paper demonstrates the growing importance of GVCs since 1995 and discusses the differences between economies, industries and goods and services. At the same time, the paper also highlights several shortcomings of existing data and clearly shows the need for new indicators of GVCs. Important policy issues like the impact of GVCs on the competitiveness of countries and attractiveness for international investments can only be addressed by new and better metrics. 
DSTI/DOC(2012)3

\section{The emergence of GVCs}

GVCs have been associated in the economic literature with different concepts such as 'global production sharing' (Yeats, 1997), 'international fragmentation' (Jones and Kierzkowski, 1990), 'vertical specialisation' (Hummels and Yi, 1999), 'multistage production' (Dixit and Grossman, 1982), 'subcontracting', 'offshoring' and 'outsourcing'. The different terms all relate to the increasing importance of vertical production/trading chains across countries, although some differences exist among them. Fragmentation theory e.g. merely focuses on production activities and discusses how international fragmentation takes place if costs can be reduced due to differences in labour productivity (Ricardian model) and/or differences in factor supplies and prices (Heckscher-Ohlin model) between locations. The concept of GVCs is typically interpreted more broadly encompassing all activities of firms' value chains including production, distribution, sales and marketing, R\&D, innovation, etc. Hence, also other motivations than cost reductions are driving GVCs like e.g. the entry into new emerging markets and the access to strategic assets and foreign knowledge.

Firms seek to optimise their production processes by locating various production stages across different sites according to the most optimal location factors across countries. As production was earlier concentrated and integrated in one location, firms have increasingly been restructuring their operations internationally e.g. through the outsourcing and offshoring of activities (OECD, 2007). Outsourcing typically involves the purchase of intermediate goods and services from outside specialist providers, while offshoring refers to purchases by firms of intermediate goods and services from foreign providers, or to the transfer of particular tasks within the firm to a foreign location (Figure 1). Offshoring thus includes both international outsourcing (where activities are contracted out to independent third parties abroad) and international in-sourcing (to foreign affiliates).

Decisions on which activities to source outside the firm (and potentially across borders) and which ones to keep internally (but possibly in a foreign affiliate) are determined by the existence of transaction costs, the complexity of inter-firm relationships and asset-specificity. Research has for example shown that firms are more reluctant to source more complex or high-value-added activities externally, as these are often considered strategic to a firm's core business. Reversely firms often relocate high-volume production that requires low skills or standard technologies to external providers that may have cheaper or more efficient production capabilities. This would allow the firm to focus its activities on areas in which it has a comparative advantage, or allow it to engage in new, often high-value-added business activities. Evidence suggests that the organisation of international production networks differs between industries and countries.

Transaction costs differ between industries and thus different organisations of GVCs have emerged along industry lines. Gereffi et al. (2005) have presented a theory of GVCs, discussing different types of governance and relating these types to factors such as the complexity of transactions, the ability to codify transactions and capabilities in the supply bases. GVCs are typically organised around different players like lead firms, global suppliers, platform leaders, etc. and the roles and mandates of firms in GVCs directly depend on the types of linkages between the different actors. Dynamics in GVCs cause actors and linkages to change over time as (smaller) firms might upgrade their activities and reinforce their positions within GVCs.

Multinational firms (MNEs) play a prominent role in global value chains because of their numerous affiliates abroad. These affiliates are not only engaged in serving local markets in the host country, but have become essential links in GVCs as they serve other (neighbouring) markets and produce inputs for other affiliates in the multinational's network. Theories of MNEs traditionally distinguish between horizontal and vertical MNEs, where the former are motivated by the desire to place production close to customers and avoid trade costs (e.g. tariff jumping) while at the same time realising economies of scale. 
Vertical MNEs have become especially important in GVCs as they undertake different stages of production in different countries; consequently, the production in one country serves as input for production activities in other countries. The cross-border trade between multinational firms and their affiliates, often referred to as intra-firm trade, accounts nowadays for a large share of international trade in goods. A growing part of such intra-firm trade concerns the exports and imports by foreign affiliates that manufacture (part of) products destined for other markets.

Figure 1 Outsourcing and offshoring

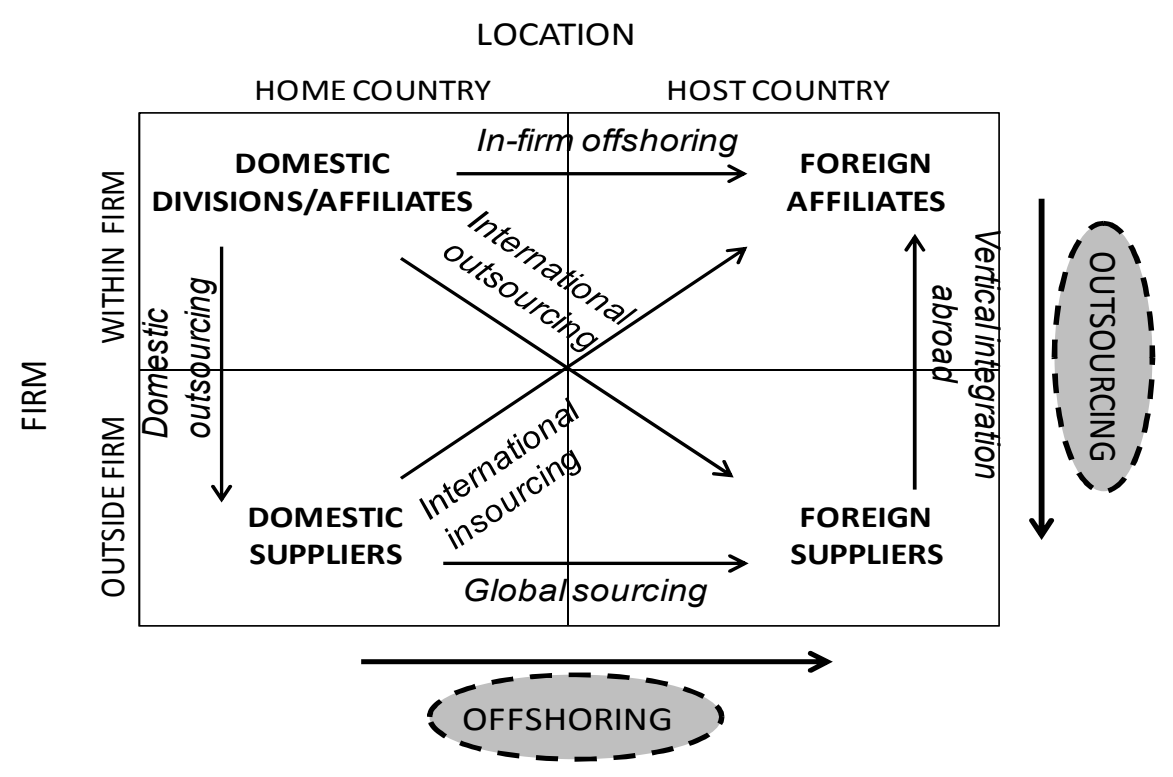

Source: based on Van Welsum and Vickery (2004), Miroudot et al. (2009) and Sturgeon (2009).

\section{Are there any stylised facts on GVCs based on trade data?}

The most obvious data for comparative analysis of GVCs across countries are international trade data as they are available for a large number of countries and at a very high level of (industry/product) disaggregation. Trade data for countries indeed point to a stronger growth of trade relative to GDP, with some countries displaying trade/GDP ratio's above 100\% during the last decades (Figure 2). The increasing trade/GDP ratios are assumed to follow directly from the growing importance of GVCs since intermediates are transferred several times across borders before the goods/services are sold to the final customer. As international trade data are expressed in output terms, they include the value of intermediates imported at each border crossing. In contrast, GDP is a value added concept and captures only the domestic content/value that countries are adding in the production of goods and services. 
Figure 2 Trade/GDP ratio (average of imports and export in \% of GDP)

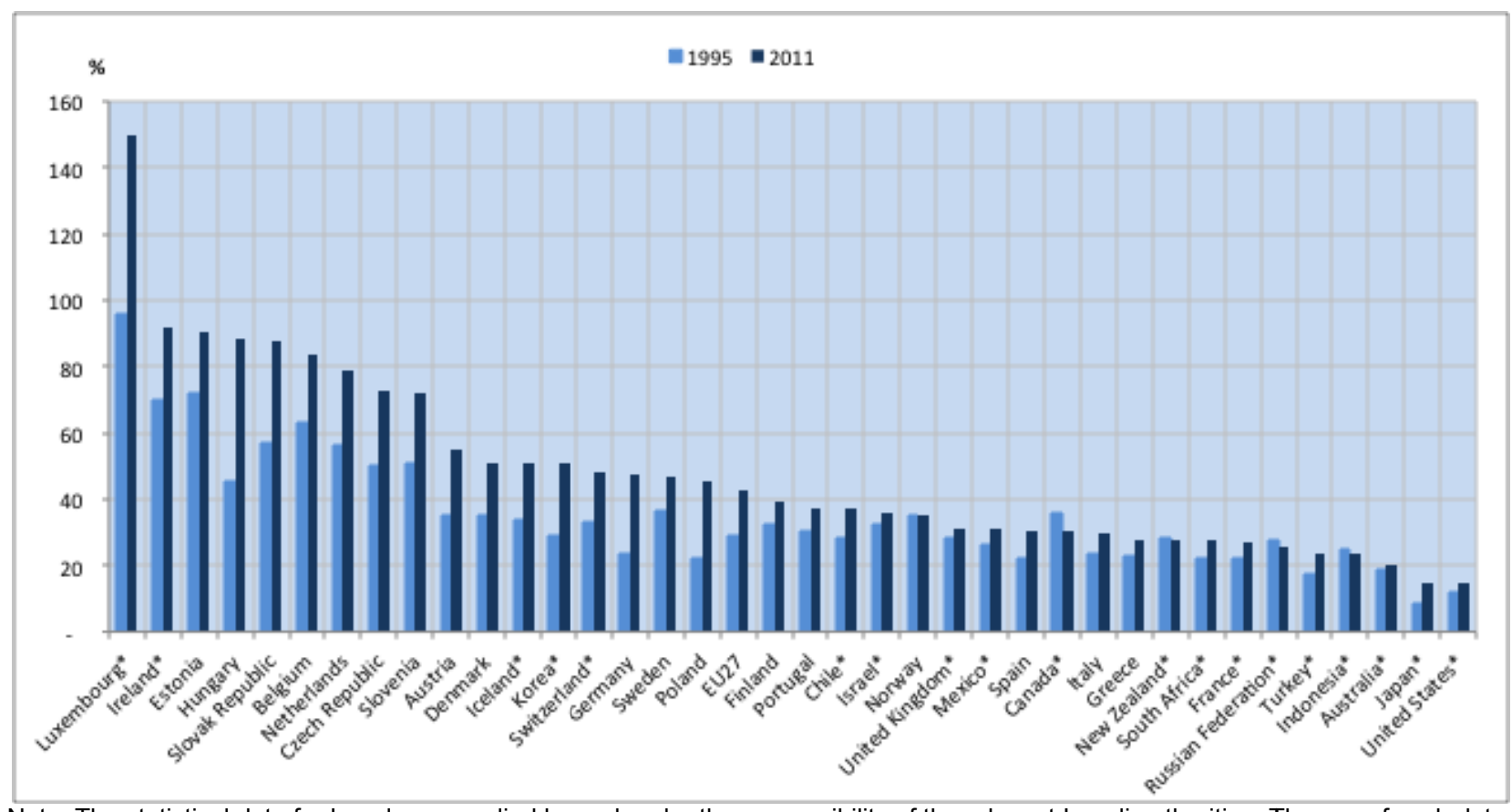

Note: The statistical data for Israel are supplied by and under the responsibility of the relevant Israeli authorities. The use of such data by the OECD is without prejudice to the status of the Golan Heights, East Jerusalem and Israeli settlements in the West Bank under the terms of international law. *: 2010

Source: OECD, Annual National Accounts.

The fact that trade data suffer from a 'double-counting' problem and tend to overstate the implicit value or factor content exchanged between countries has also contributed to a rising GDP elasticity of trade. This multiplier effect of trade relative to GDP is believed to have amplified the strong impact of the recent crisis on trade and investment. But this is not only due to the increasing spread of GVCs as also other factors help explain the dramatic drop in trade during and after the recent crisis. ${ }^{4}$

When analysing trade data in more detail, some stylised facts arise that seem at odds with (rather than supporting) the increasing importance of GVCs. A first surprising observation is that trade data do not reflect the increasing importance of intermediate trade over the last decades (Figure 2). Recent OECD work has used the United Nations' Broad Economic Categories (BEC) classification to identify intermediate goods and the OECD Input-Output Database to identify intermediate services ${ }^{5}$ (Miroudot et al., 2009). The results show that intermediate inputs indeed make up for the majority of international trade ( $56 \%$ of goods trade and $73 \%$ of services trade), but that this share in total trade has remained fairly stable between 1995 and 2006 (Figure 3). Trade in intermediate inputs grew at an average annual rate of $6.2 \%$ for goods and 7\% for services between 1995 and 2006, but trade in final goods and services grew at the same

$4 \quad$ Other explanatory factors are in the first place composition effects since trade originates mainly from manufacturing while services account for the largest part of GDP. Additional factors like the collapse in internal demand and production, the fiscal stimulus plans of national governments which were more targeted at the non-tradable sector, the rise of 'murky' protectionism and the credit crunch directly aggravating problems in trade finance are also at play.

5. The BEC classification groups commodities according to their main end use into capital goods, intermediate goods and consumption goods, the three basic classes of goods in the System of National Accounts. The BEC is only available for goods but not for services trade. 
pace. Similar observations about the stable share of intermediates in total trade were also reported in Hummels et al. (1999) and Chen et al. (2005).

The BEC classification has recently received some criticism as it is basically the result of a (subjective) judgment based on descriptive characteristics from already some time ago and may thus not reflect any longer the actual use of goods in fast changing industries. By proposing a more updated classification of intermediates and final goods for a couple of industries, Sturgeon and Memedovic (2010) indicated that intermediates trade grew stronger (relatively to trade in final goods) particularly in the electronics and apparel and footwear industries during the last decades; in the automotive industry however, intermediates and final goods seem to show a same growth pattern.

Figure 3 World trade of intermediate goods and services (as $\%$ of total world trade)

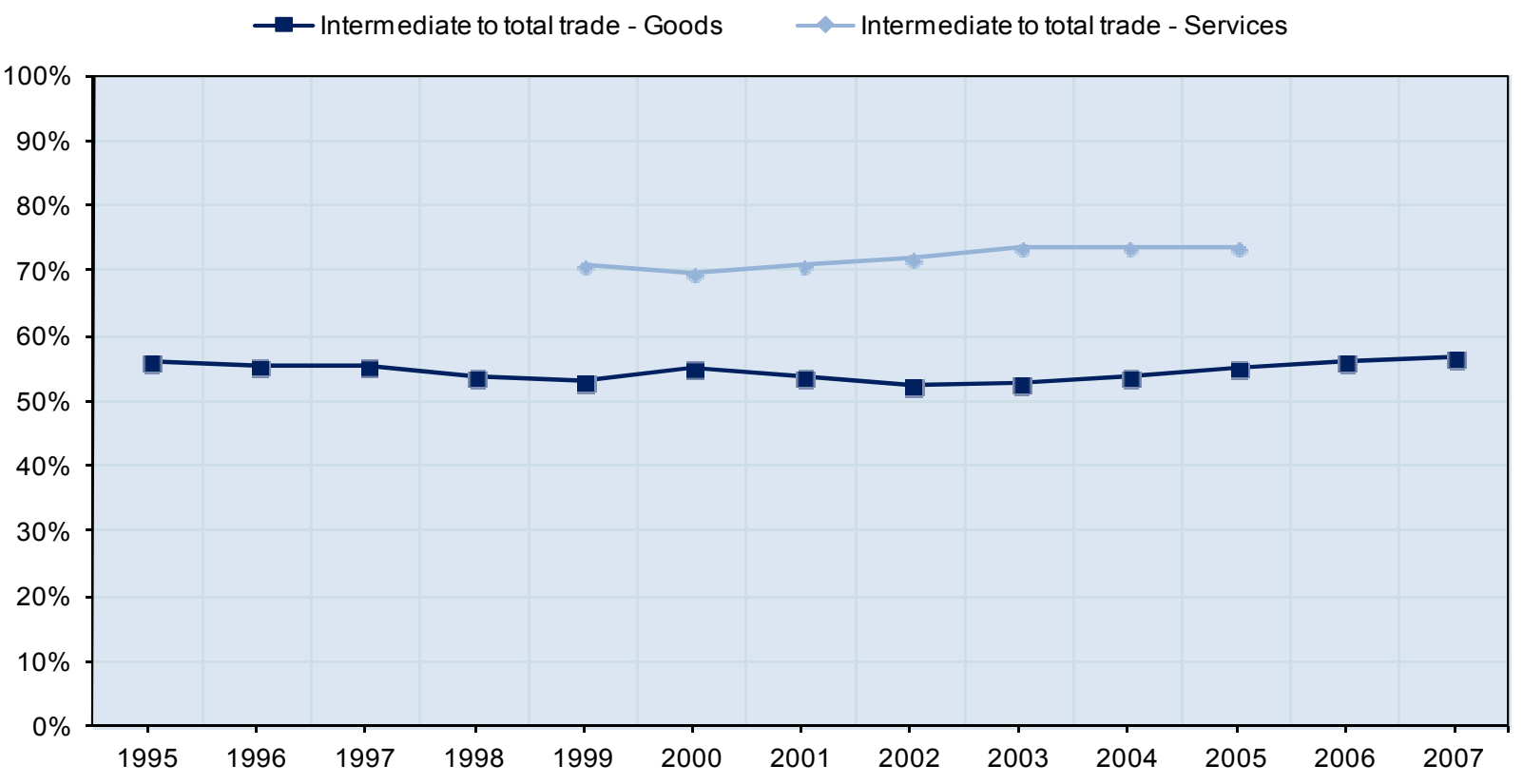

Source: Miroudot et al. (2009).

Also data on intra-firm trade, i.e. trade between parent firms and their affiliates within MNEs do not seem to overwhelmingly support the increasing spread of GVCs. It is generally assumed that the growing importance of MNEs in GVCs results in a growing part of foreign affiliates' production being used as intermediate inputs by parent firms and other affiliates within the multinational network. But just as for trade in intermediate goods and services, the available data (only for a limited number of countries) show that though intra-firm trade is important (especially in countries like the United States, Israel, Sweden, Italy and more recently Poland), this category of trade shows a relatively stable pattern over the last decade (Figure 4). 
Figure 4 Intra-firm exports in total exports of affiliates under foreign control, for selected countries (as \% of total exports)

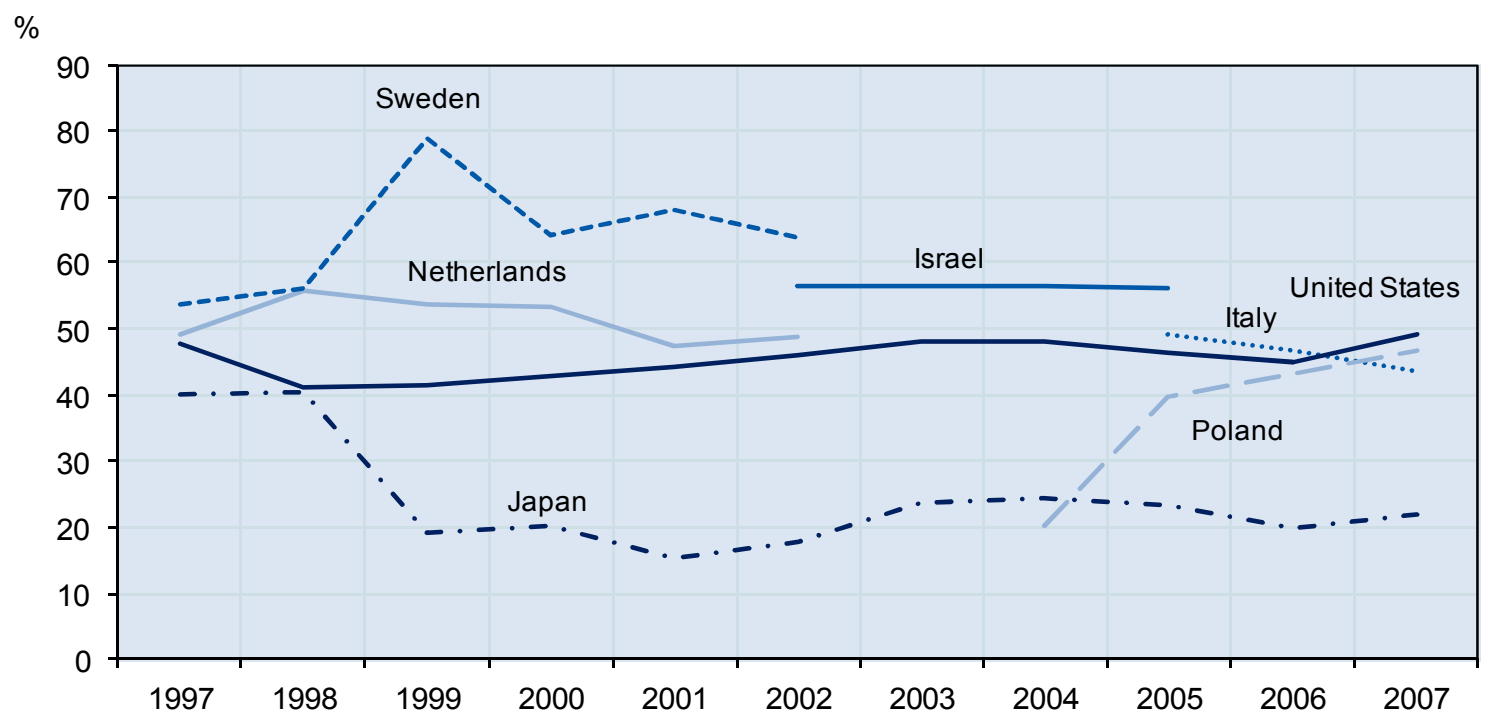

Source: OECD (2010).

Third, aggregate data on intra-industry trade, i.e. trade within the same industry ${ }^{6}$, show an upward trend in several countries during the last decade and are as a result, very high in recent years (Figure 5). A popular assessment is that GVCs drive this evolution since industry trade data often include intermediate and final goods (e.g. motor parts and passenger cars). International fragmentation is however only one explanation for this trend, next to the increasing importance of horizontal (i.e. similar goods of different varieties) and vertical (i.e. products characterised by quality differences) product differentiation for final goods (Krugman, 1979; Lancaster, 1979; Spence, 1976; Dixit and Stiglitz, 1977; Falvey, 1981). Empirical research has largely shown that the rise in intra-industry trade is particularly due to the two-way trade of vertically differentiated products; two-way trade of horizontally differentiated products is found to be relatively smaller (see for an overview Fontagné et al., 2006). More recently, Ando (2006), Brulhart (2008) and Turkcan (2010) argued however that part of this vertical intra-industry trade is related to back and forth trade of intermediate goods and services within GVCs.

$6 \quad$ Intra-industry trade flows are conventionally defined as the two-way exchange of goods within standard industrial classifications. One measure to measure intra-industry is the Grubel-Lloyd index based on commodity group transactions. Thus, for any particular product class $i$, an index of the extent of intra-industry trade in the product class $\mathrm{i}$ between countries $\mathrm{A}$ and $\mathrm{B}$ is given by the following ratio:

$$
I I T_{i . A B}=\left(\frac{\left(X_{i}+M_{i}\right)-\left|X_{i}-M_{i}\right|}{\left(X_{i}+M_{i}\right)}\right) \bullet 100
$$

This index takes the minimum value of zero when there are no products in the same class that are both imported and exported, and the maximum value of 100 when all trade is intra-industry (in this case $\mathrm{Xi}$ is equal to $\mathrm{Mi}$ ). A degree of caution must be used when comparing and interpreting intra-industry indices because their measurement crucially depends on the level of aggregation chosen for the analysis. 
There is a general consensus that existing trade data are not detailed enough and are not collected on the right level of analysis to analyse the international fragmentation and GVCs. Trade statistics have been designed to capture trade flows in final products while nowadays most trade is of intermediate products, hence the increasing need for measuring trade in terms of value added (Kierzkowski and Chen, 2010). Likewise, comparative advantage is typically expressed in terms of (sub-)industries according to earlier trade models, but GVCs have shifted the analysis of countries' competitiveness to activities and tasks. A clear need arises for the reassessment of the existing data and for developing new and more appropriate data and indicators.

Figure 5 Intra-industry trade (as \% of total trade), average 1997-2008

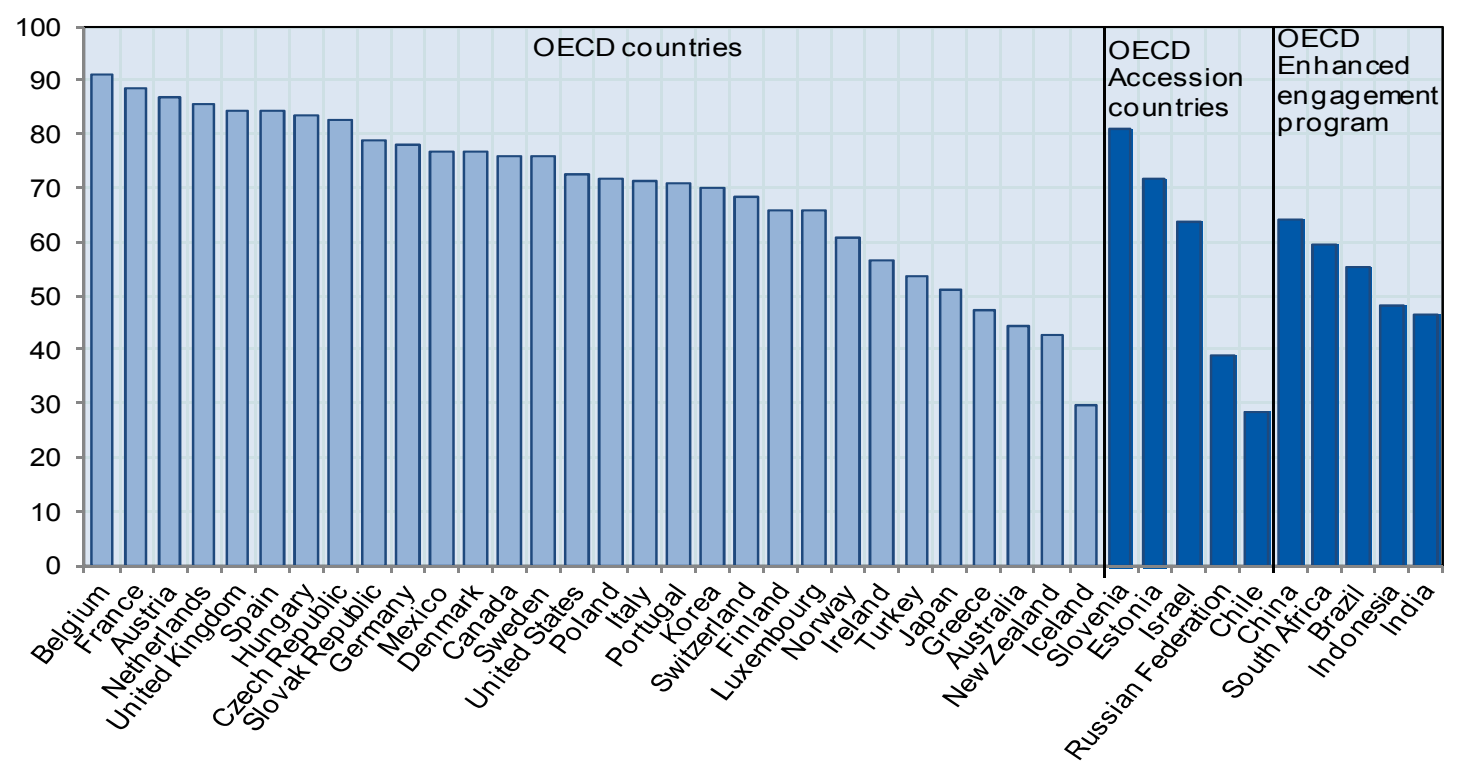

Note: The statistical data for Israel are supplied by and under the responsibility of the relevant Israeli authorities. The use of such data by the OECD is without prejudice to the status of the Golan Heights, East Jerusalem and Israeli settlements in the West Bank under the terms of international law.

Source: OECD (2010)

\section{Input-Output data confirm the increasing importance of GVCs}

The growing importance of GVCs has increased the attention for input-output (I/O) analysis, as I/O-tables offer (complementary) information on the value of intermediate goods and services. An important advantage of I-O tables is that they classify goods according to their use (as input into another sector's production or as final demand); in contrast, classification schemes (like e.g. BEC) divide goods into intermediate and other categories based on their descriptive characteristics. In addition, $\mathrm{I} / \mathrm{O}$-tables include information on inputs of/in services sectors, allowing for the analysis of the fast growing category of services trade.

The OECD has estimated harmonised I/O-tables of different countries approximately, using a standard industry list based on ISIC Revision 3. The latest set of OECD I/O-Tables consists of matrices of inter-industrial transactions of goods and services (domestically produced and imported) in current prices for 43 countries covering the years 1995, 2000 and 2005 or nearest years. A significant number of emerging countries are included reflecting the fact that countries like India, China, etc have become important actors in the current globalisation. A number of indicators have been calculated on offhsoring and vertical specialisation which overall show, in contrast to trade data, the increasing importance of GVCs. 
The OECD I/O tables distinguish between domestic intermediates and intermediates that have been imported from outside the country. The growing importance of international sourcing across industries and countries is clearly reflected in the data: the ratio of imported to domestic inputs has increased significantly between 1995 and 2005 in most countries (Figure 6). Some resource-rich countries like Canada, Norway and Australia showed however a small decrease in this ratio over the considered period, which might be related to growing role of natural resources since 2002. Smaller countries import relatively more intermediates from abroad which is consistent with their limited size and hence their typically larger international orientation. In Ireland e.g., domestic and international sourcing are reported to be equally important, meaning that the same amount of intermediates is sourced internationally as nationally (i.e. within the Irish economy).

It should be noted that most of the countries in the OECD Input-Output database applied the so-called proportionality assumption in the construction of their import matrices. Because the actual use of imported inputs is often not available, this technique assumes that an industry uses an import of a particular product in proportion to its total use of that product. Recent studies have questioned the accuracy of this assumption; Winkler and Milberg (2009) showed for Germany that the cross-sectonal variation in the use of domestic inputs significantly differs from the cross-sectional variation in the use of imported inputs. In addition, Koopman et al. (2008) showed that the intensity of imported inputs differs between the production of processing exports and other production. This should be taken into account in the following discussion empircal indicators on offshoring and vertical specialisation.

Figure 6 Imported intermediates/domestic intermediates, by country

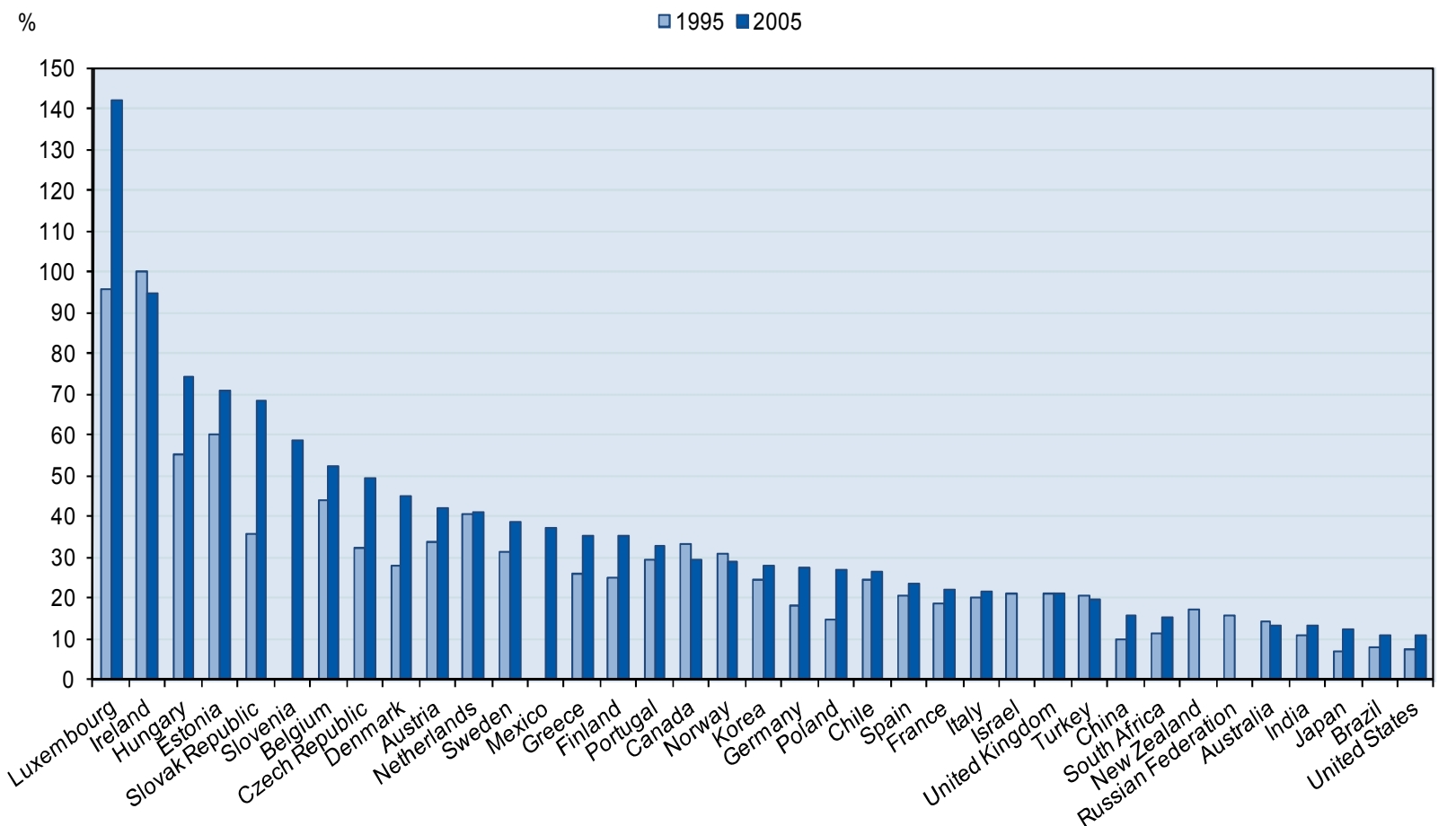

Note: The statistical data for Israel are supplied by and under the responsibility of the relevant Israeli authorities. The use of such data by the OECD is without prejudice to the status of the Golan Heights, East Jerusalem and Israeli settlements in the West Bank under the terms of international law.

Source: OECD (2010). 


\subsection{Indicators on offshoring and outsourcing}

Input-Output information allows for the construction of a number of indicators that shed some light on the (recent) trend of offshoring; the empirical measurement of offshoring (see figure 1) has proven to be difficult until now mainly because of data availability (OECD, 2007; GAO, 2004). One indicator measures companies' purchases of intermediate inputs from foreign providers, which can be independent suppliers (through transactions at arms-length) or foreign affiliates (through intra-firm trade within the multinational network) abroad. Following Feenstra and Hanson $(1996,1999)$, the indicator is calculated as: ${ }^{7}$

$$
\mathrm{OFFSH}=\sum_{j} \sum_{i} x_{m}{ }^{i j} /\left(\sum_{j} \sum_{i} x_{d}{ }^{i j}+\sum_{j} \sum_{i} x_{m}{ }^{i j}\right)
$$

where $x_{d}{ }^{i j}$ and $x_{m}{ }^{i j}$ are the domestic and imported transactions of intermediates from sector $i$ to sector $j$ respectively ${ }^{8}$.

In line with the increasing importance of imported intermediates, offshoring has grown in almost all countries over the period 1995-2005 (Figure 7). Although the level of offshoring in large emerging countries such as Brazil, India, Argentina, and China remains lower than the OECD average, the data show that offshoring of intermediates has also increased in these countries.

\section{Figure 7 Growth in offshoring, by country, 1995-2005}

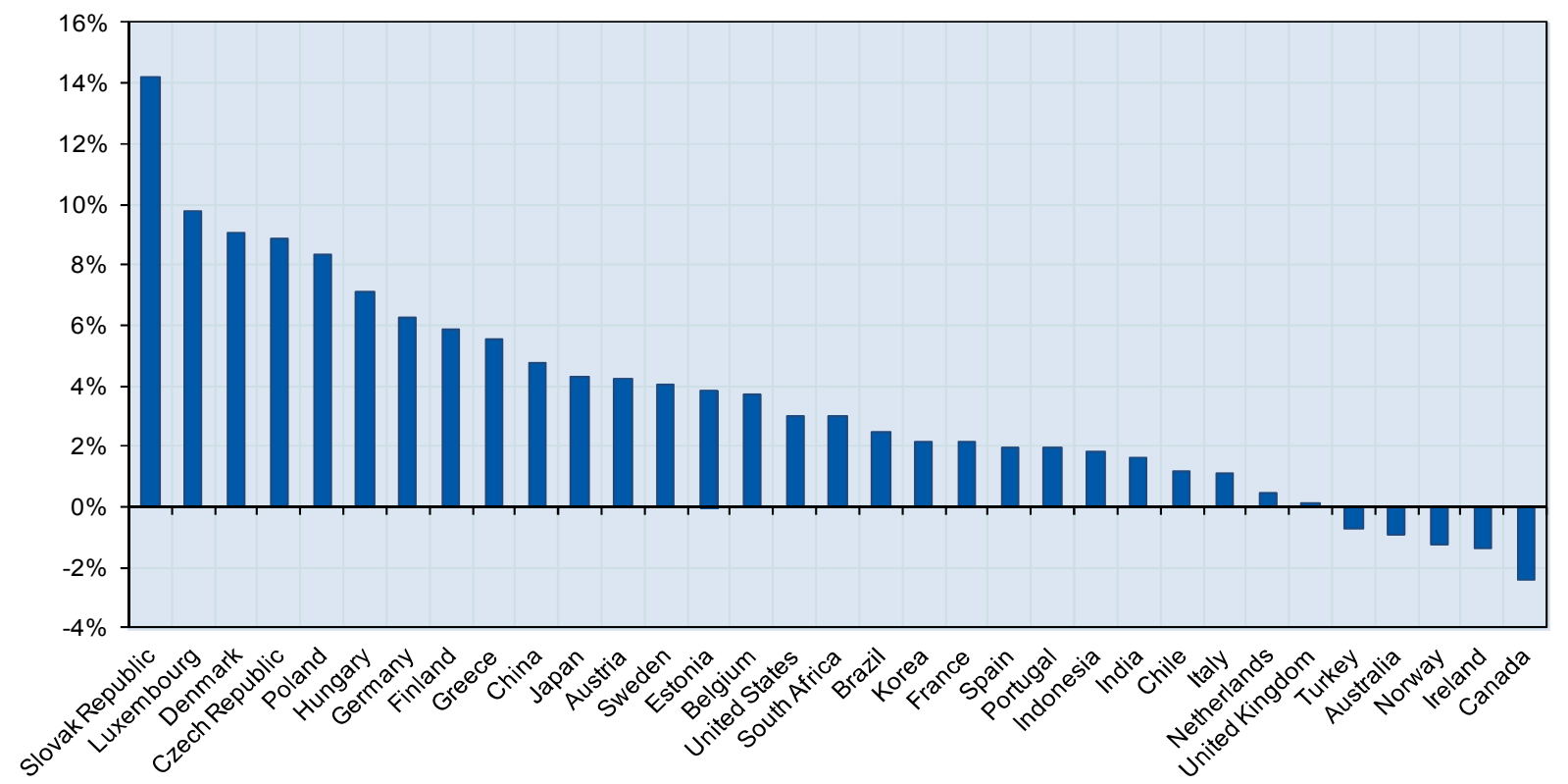

Note: The statistical data for Israel are supplied by and under the responsibility of the relevant Israeli authorities. The use of such data by the OECD is without prejudice to the status of the Golan Heights, East Jerusalem and Israeli settlements in the West Bank under the terms of international law.

Source: OECD (2010).

$7 \quad$ Feenstra and Hanson $(1996,1999)$ have used this indicator as proxy for outsourcing, but following the definitions of outsourcing and offshoring discussed above, the indicator should be interpreted as a measure of offshoring.

Other indicators on offshoring have been presented; see for an overview De Backer and Yamano (2007). 
The calculation of the same indicator seperately for manufacturing and services directly shows why services offshoring has attracted a lot of attention recently. Different studies have discussed the growing importance of this phenomenon and have estimated the number of service jobs that have been/will be lost because of the offshoring of activities to other countries [see for an overview OECD (2007) ]. The I/O results clearly suggest that the emergence of global value chains increasingly stretches out to services sectors: offshoring has increased significantly over the period 1995-2005 especially in the services sector and this in almost all countries. In contrast, while the international sourcing of intermediates is on average more important in manufacturing, ${ }^{9}$ it has increased relatively little over the period 1995-2005 in most countries except for Eastern European countries. Following their adhesion to the European Union, these countries have attracted a large number of (Western European) multinational companies and as a result of the international sourcing strategies of these companies, manufacturing offshoring in these countries has strongly grown (Figure 8).

\section{Figure 8 Offshoring in manufacturing and services, by country}

\section{Manufacturing}

$\square 1995=2005$

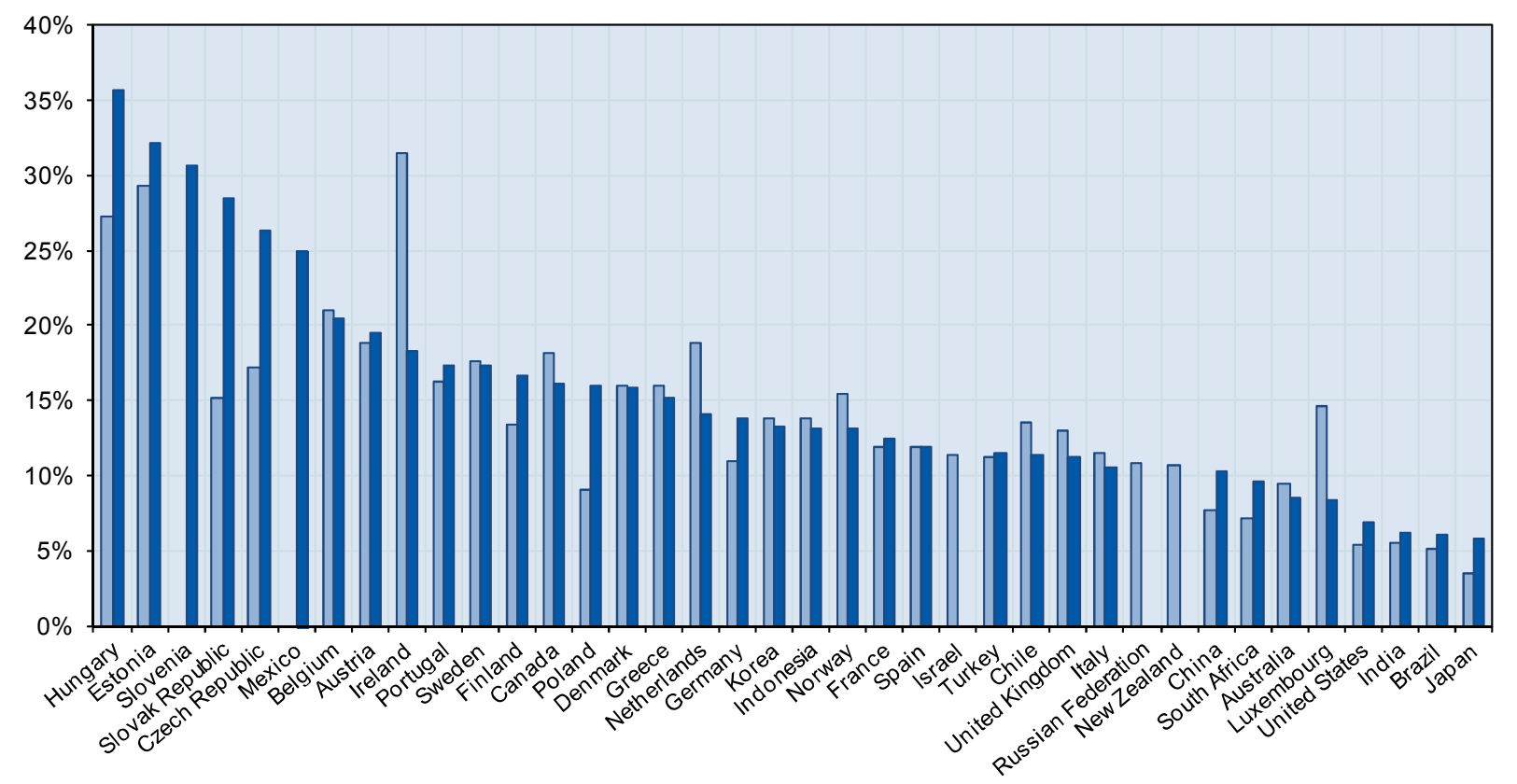

9 The sourcing of intermediates abroad appears to be relatively more important in higher technology industries than in lower technology industries, reflecting the in general higher complexity of technology intensive goods as they typically require a broad range. 


\section{Services}

$\square 1995=2005$

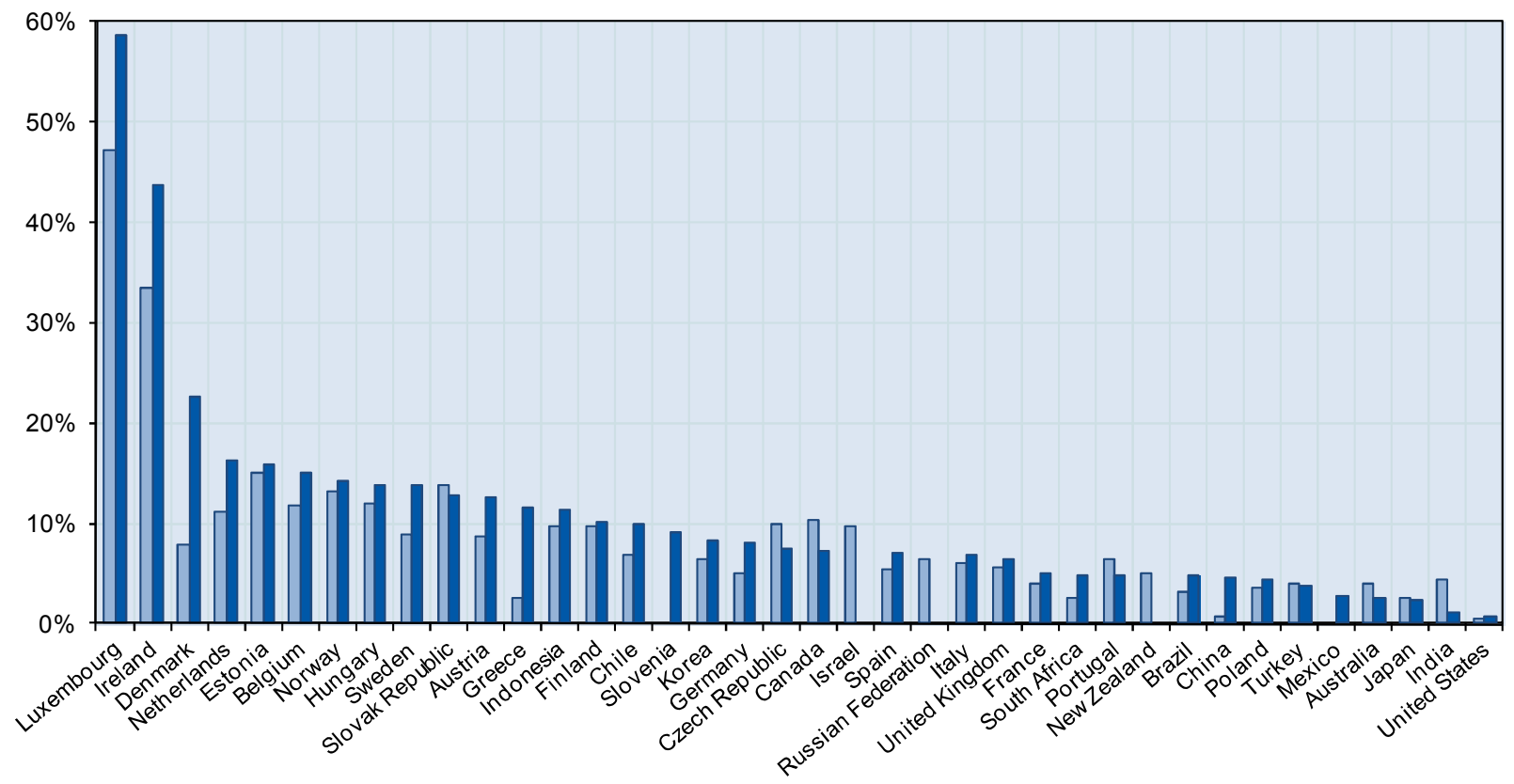

Note: The statistical data for Israel are supplied by and under the responsibility of the relevant Israeli authorities. The use of such data by the OECD is without prejudice to the status of the Golan Heights, East Jerusalem and Israeli settlements in the West Bank under the terms of international law..

Source: OECD (2010).

\subsection{Indicators on vertical specialisation}

As the share of intermediates trade in total trade showed a relative stable pattern during the last decades, some authors have argued that the increasing importance of GVCs is particularly demonstrated by a subcategory of intermediates, more specifically those that are imported and used to produce goods that are exported (Chen et al., 2005). The emergence of GVCs makes that imports and exports increasingly move together because of the sequential production process and back-and-forth trade between countries. $\mathrm{I} / \mathrm{O}$ tables measure the interrelationships between the producers of goods and services (including imports) within an economy and the users of the same goods and services (including exports). As such they can be used to estimate the contribution that imports make in the production of any good and service for export.

By introducing the term 'vertical specialisation', ${ }^{10}$ Hummels et al. (2001) calculated the direct and indirect imported inputs that are included in a country's exports. For example, if a motor car manufacturer imports certain components (e.g. the chassis) the direct import contribution will be the ratio of the value of the chassis to the total value of the car. And if the car manufacturer purchases other components from domestic manufacturers, who in turn use imports in their production process, those imports must be included in the car's value. Hence, these indirect imports should be included in the overall contribution of imports to the production of motor cars for export.

10

As a result of GVCs and the corresponding geographical fragmentation of activities, countries become vertically specialised within the production process for some good or services as companies tend to concentrate different production stages for a single good in each country. The vertical specialization measures try to reflect this process by which different countries become part of a single production chain, linking the imported inputs required by one country with its exports. 
A first indicator of vertical specialisation $\left(\mathrm{VS}_{\mathrm{i}}\right)$ is calculated as the import content embodied in country i's exports:

$$
\mathrm{VS}_{\mathrm{i}}=\mathrm{u} * \mathrm{Am}_{\mathrm{i}} *\left[\mathrm{I}-\mathrm{Ad}_{\mathrm{i}}\right]^{(-1)} * \mathrm{X}_{\mathrm{i}} / \sum \mathrm{X}_{\mathrm{i}}
$$

where $\mathrm{Am}_{\mathrm{i}}$ and $\mathrm{Ad}_{\mathrm{i}}$ contain the input-output coefficients of country $\mathrm{i}$ for imported and domestic transactions respectively; $\mathrm{u}$ denotes an $1 \mathrm{x} \mathrm{n}$ vector each of whose components is unity, the matrix $\mathrm{X}_{\mathrm{i}}$ is an $\mathrm{nx} 1$ vector of exports of country $\mathrm{i}$ and $\sum X_{\mathrm{i}}$ is total country i's exports. This vertical trade is made up of intra-firm trade within multinational companies at the one side and vertical trade at arm's length relationships between independent companies at the other side.

The results clearly show that countries' exports are increasingly composed of intermediate inputs that are imported from abroad; between 1995 and 2005, the import dependency of exports increased in almost all countries (Figure 9). This increase was particularly strong in Luxembourg, Poland, the Slovak Republic, China and Greece. In contrast, the import content of Canadian exports decreased between 1995 and 2005 from $30 \%$ to $24 \%$.

The import content of exports represented in 2005 on average $23 \%$ of total trade among OECD countries; in some countries such as Luxembourg, Hungary, Ireland and Estonia, the import content of exports exceeded $50 \%$ in 2005. Other countries like the United States, Russian Federation, Australia, Brazil and India import relatively less vertical trade than other countries because of their size. These typically smaller values of vertical specialisation for larger countries reflect that more links in the GVC are located within the (large) country.

Vertical specialisation takes place both within MNEs and through offshoring to external suppliers. The results for the VS1 measure suggest that the import content of exports is closely related to the presence of MNEs. The increase in vertical specialisation comes most clear in countries with a high multinational presence. Foreign affiliates in different host countries produce intermediates that are then exported to final consumers, but also to other affiliates and to the headquarters of the multinational company.

The degree of vertical specialisation is found to be particularly large in more basic industries that are heavily using primary goods like cokes and refined petroleum, basic metals, chemicals, and rubber and plastics. A second group of industries concern higher technology intensive industries that produce modular products. Parts and components are often produced in one country before they are exported to another country where the assembly is taking place. This international division of labour is found in industries like electrical machinery, radio/television and communication equipment, office, accounting and computing machinery but also motor vehicles (Figure 10). 
Figure 9 Vertical specialisation VS1 (import content of exports), by country

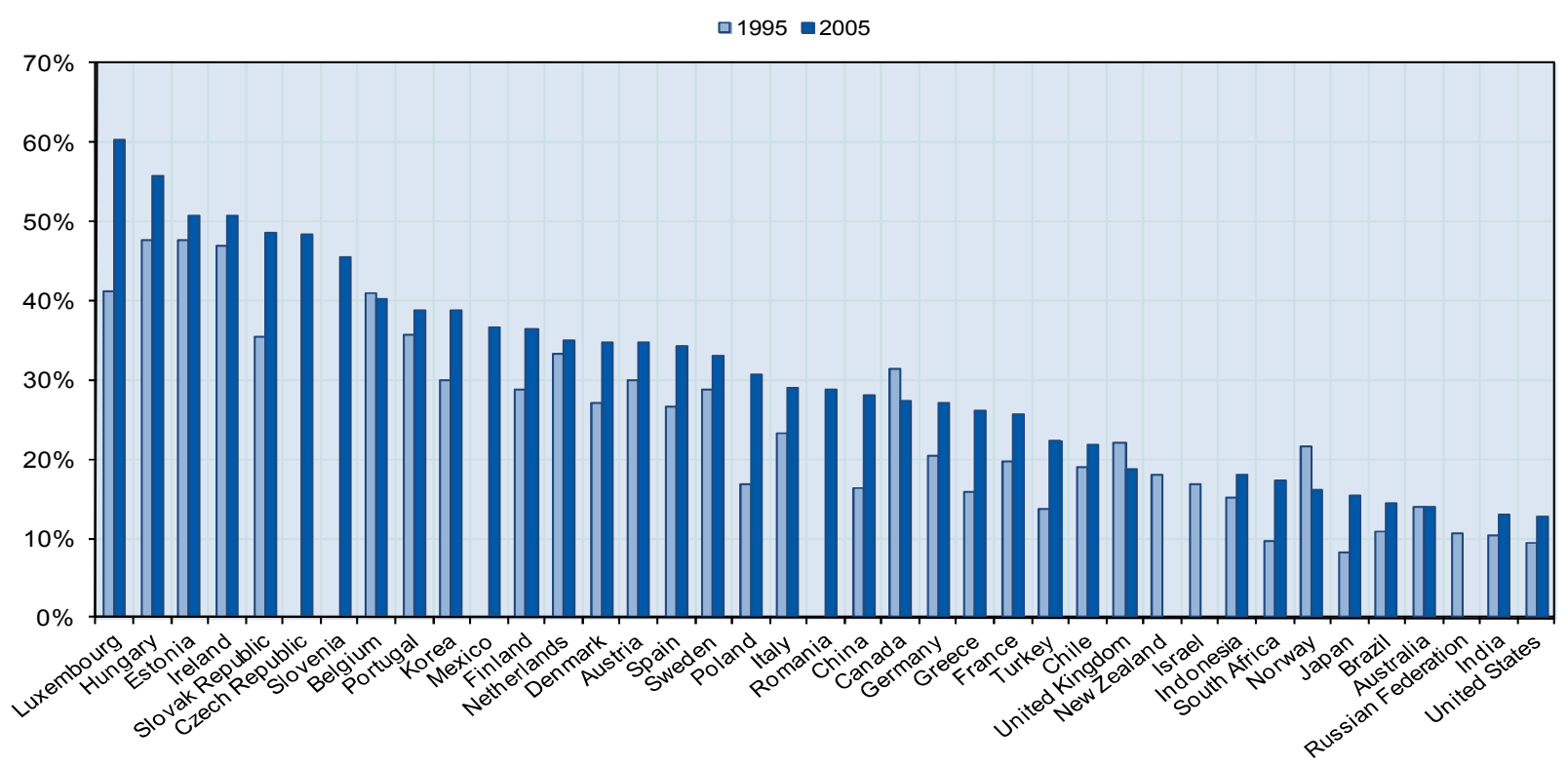

Note: The statistical data for Israel are supplied by and under the responsibility of the relevant Israeli authorities. The use of such data by the OECD is without prejudice to the status of the Golan Heights, East Jerusalem and Israeli settlements in the West Bank under the terms of international law.

Source: OECD (2010).

Figure 10 Vertical specialisation VS1 (import content of exports), by industry

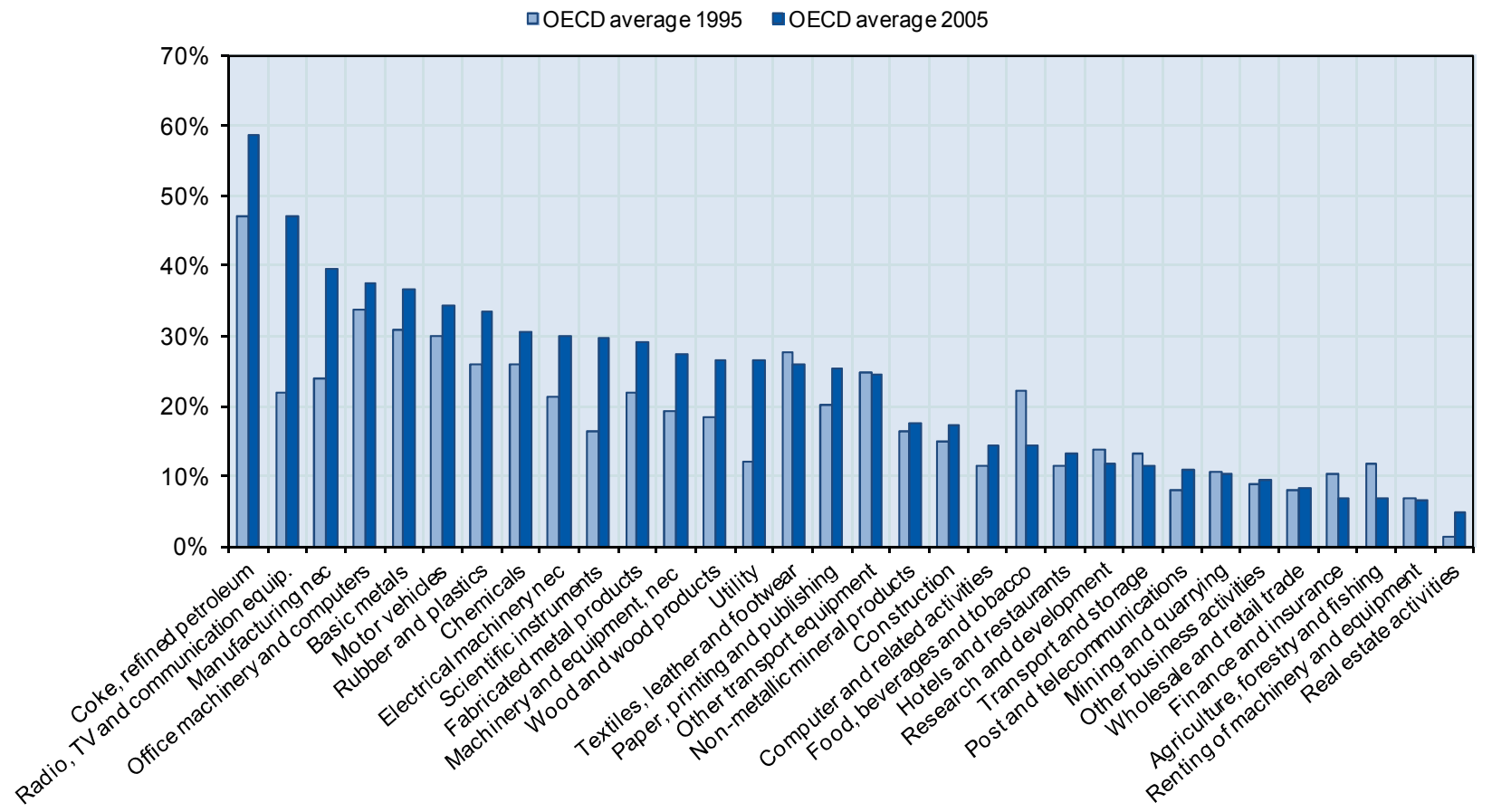

Source: OECD (2010). 
The indicator of vertical specialisation can be calculated for intermediate and final goods separately in order to analyse in more detail the specific position of countries in the vertical production process. The vertical specialisation for intermediates (VS1 $1^{\text {intermediates }}$ ) reflects especially the importance of imported intermediates for the production and exports of parts and components; hence this measure indicates the position of countries in the production of intermediates. Vertical specialisation for final products (VS1 ${ }^{\text {final }}$ ) represents the imported intermediates usage in the exports of final products and gives merely an idea about the position of countries in the final assembly process. This position of countries in GVCs is assumed to be directly related to the technological profile of countries (Uchida and Inomata, 2009): the production of parts and components for consumer goods especially in high technology intensive industries, requires on average larger technological capabilities and more advanced business processes, hence these activities will be relatively more undertaken in technology advanced countries. The assembly of parts and components into final products, even in higher technology industries, is rather based on simple routines and hence less technological advanced countries will 'specialise' in these activities.

The results for VS1 $1^{\text {intermediates }}$ and VS1 $1^{\text {final }}$ confirm this general picture (Figure 11): while countries like Hungary, Indonesia, Estonia, the Czech Republic and the Slovak Republic show a strong integration in both intermediates and final goods, they show relatively higher VS1 $1^{\text {final }}$ than $\mathrm{VS} 1^{\text {intermediates }}$ measures (Figure 10). In contrast, countries like Japan, United Kingdom and the Netherlands seem to specialise more in the production of (high value added) intermediates as they show rather higher $\mathrm{VS} 1^{\text {intermediates }}$ measures (relative to $\mathrm{VS}^{\text {final }}{ }^{\text {). }}$

Comparing the results for 1995 and 2005 reveals some interesting changes in the position of countries in GVCs: China e.g. showed in 1995 relatively higher VS1 measures for final goods indicating the strong assembly activities in the mid '90s. This VS1 ${ }^{\text {final }}$ measure has further increased over the period 1995-2005 showing the increasing importance of downstream assembly activities in China. However, at the same time, China seemed to have also moved into the more upstream production of parts of components (for the production of other intermediates), which is most likely related to the technological upgrading of the country over the years. Other studies have also suggested that some assembly activities are increasingly moved away from China to other Asian countries like Vietnam and Cambodia. 
Figure 11 Vertical specialisation VS1 (import content of exports), intermediate and final goods/services

\section{Intermediate goods/services}

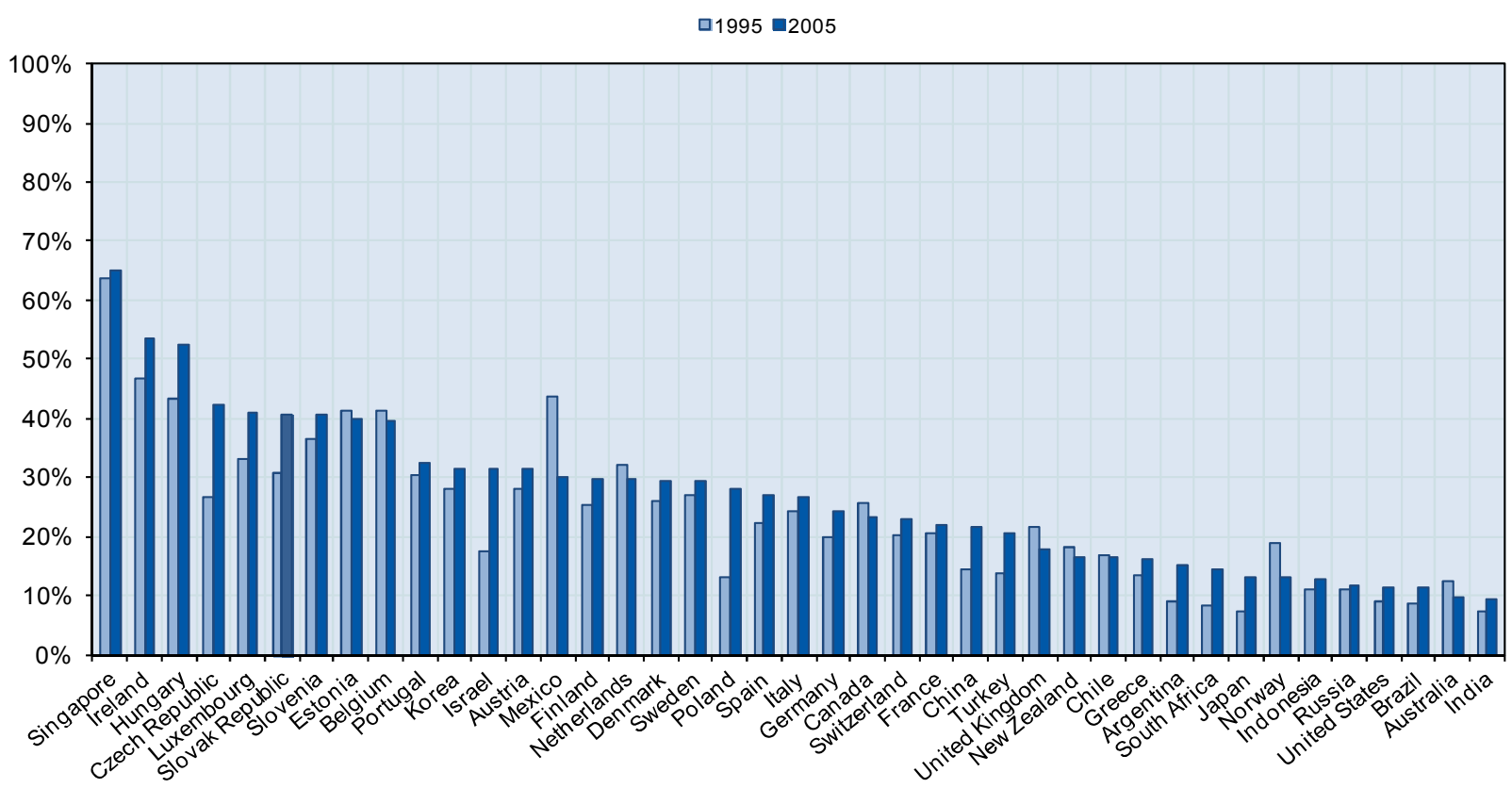

Final goods/services

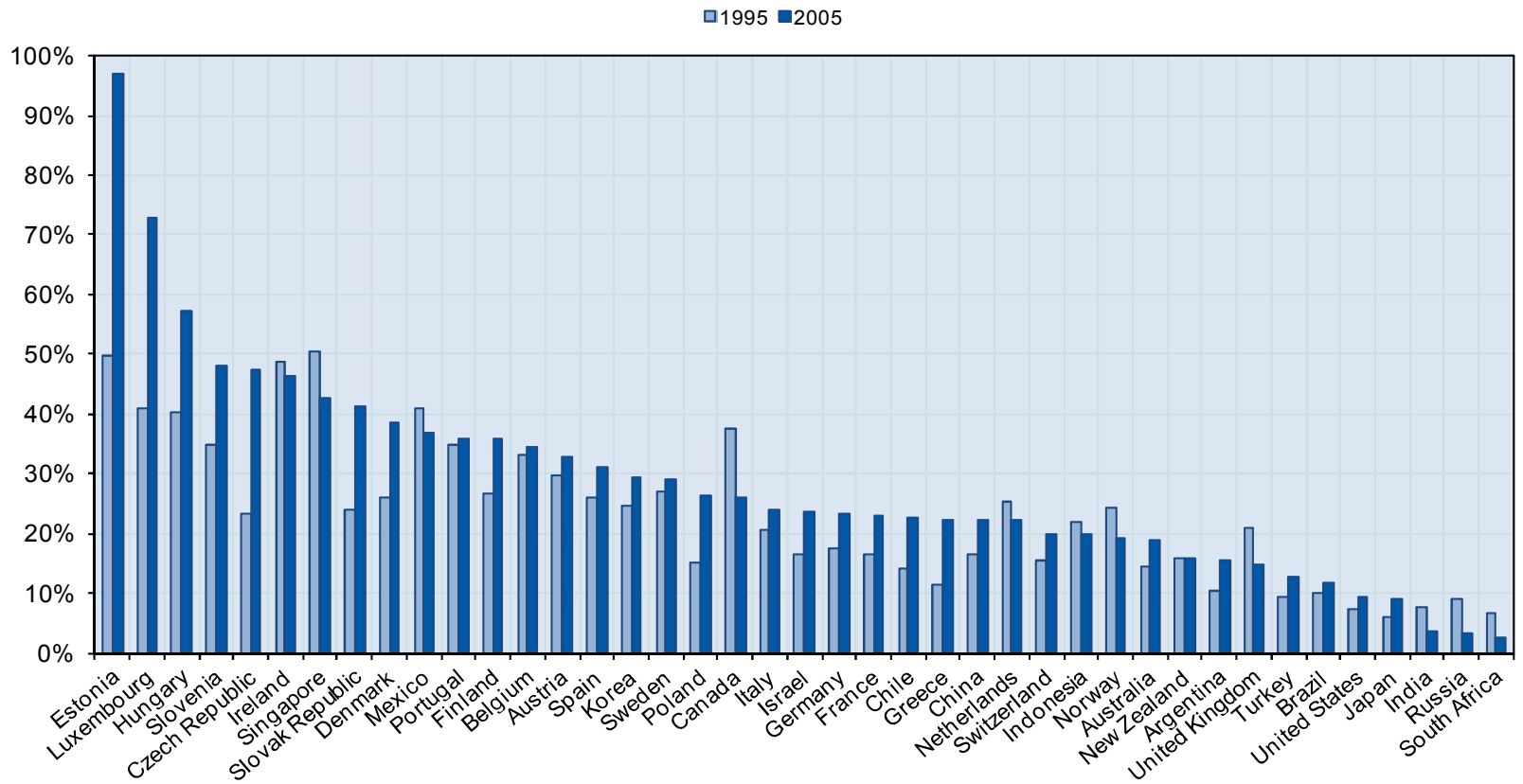

Note: The statistical data for Israel are supplied by and under the responsibility of the relevant Israeli authorities. The use of such data by the OECD is without prejudice to the status of the Golan Heights, East Jerusalem and Israeli settlements in the West Bank under the terms of international law.

Source: Calculations based on OECD I/O tables. 
The measures of vertical specialisation discussed until now look at vertical specialisation merely from the viewpoint of an exporting country demanding intermediates from abroad ('how many exports are directly and indirectly needed for the production of exports'). An alternative measure computes vertical specialisation rather from an exporting country supplying intermediate inputs abroad. This second measure, proposed by Yi (2003), indicates how much of a country's exports are used as intermediate inputs in the exports of other countries and is especially important for countries specialising in the first stages of the vertical chain ${ }^{11}$ :

$$
\mathrm{VS}_{\mathrm{i}}=\sum(\mathrm{n})\left[\mathrm{Am}_{\mathrm{n}}(\mathrm{i})\left[\mathrm{I}-\mathrm{Ad}_{\mathrm{n}}\right]^{(-1)} * \mathrm{X}_{\mathrm{i}}(\mathrm{n})\right] / \sum(\mathrm{n}) \mathrm{X}_{\mathrm{i}}(\mathrm{n})
$$

where $A_{n}(i)$ is the input coefficient matrix of country $n$ for imported transactions from country $i$, $\mathrm{Ad}_{\mathrm{n}}$ contains input-output coefficients for domestic transactions in country $\mathrm{n}$, the matrix $\mathrm{X}_{\mathrm{i}}(\mathrm{n})$ contains exports from country i to country $n, \sum(n) X_{i}(n)$ are the total exports of country $i$.

This second indicator of vertical specialisation also shows a clear upward trend between 1995 and 2005 in most of the countries, further confirming the increasing importance of global value chains and the accompanied rise in vertical trade and trade of intermediates (Figure 12). Countries like Australia and Norway because of their natural resources and Japan and the United Kingdom because of their specialisation in the production of parts and components show significantly higher values on this second indicator of vertical specialisation (relative to the VS1 measure). In contrast, countries that are more specialised in final assembly activities show relatively lower values on this second indicator. Canada shows relatively lower indicators for this second indicator (suggesting that Canada's position in GVCs stems rather from the import demand for intermediates inputs than the production of intermediates for other countries), but this indicator has showed a much more stable pattern over the period 1995-2005.

Together the two indicators show the integration of countries in the growing spread of GVCs, both as a producer of intermediates to be included in other countries' exports and as a demander of intermediates to include in own exports. The strong increase in both VS measures for China e.g. over the period 1995-2005 demonstrates in the first place that China has become more central in international production networks, both as an assembler of final products and producer of intermediates. Second, the large vertical specialisation of China (especially the still large (downstream) assembly activities) indicates that the competitiveness of China is largely built on the intermediates produced somewhere else. 


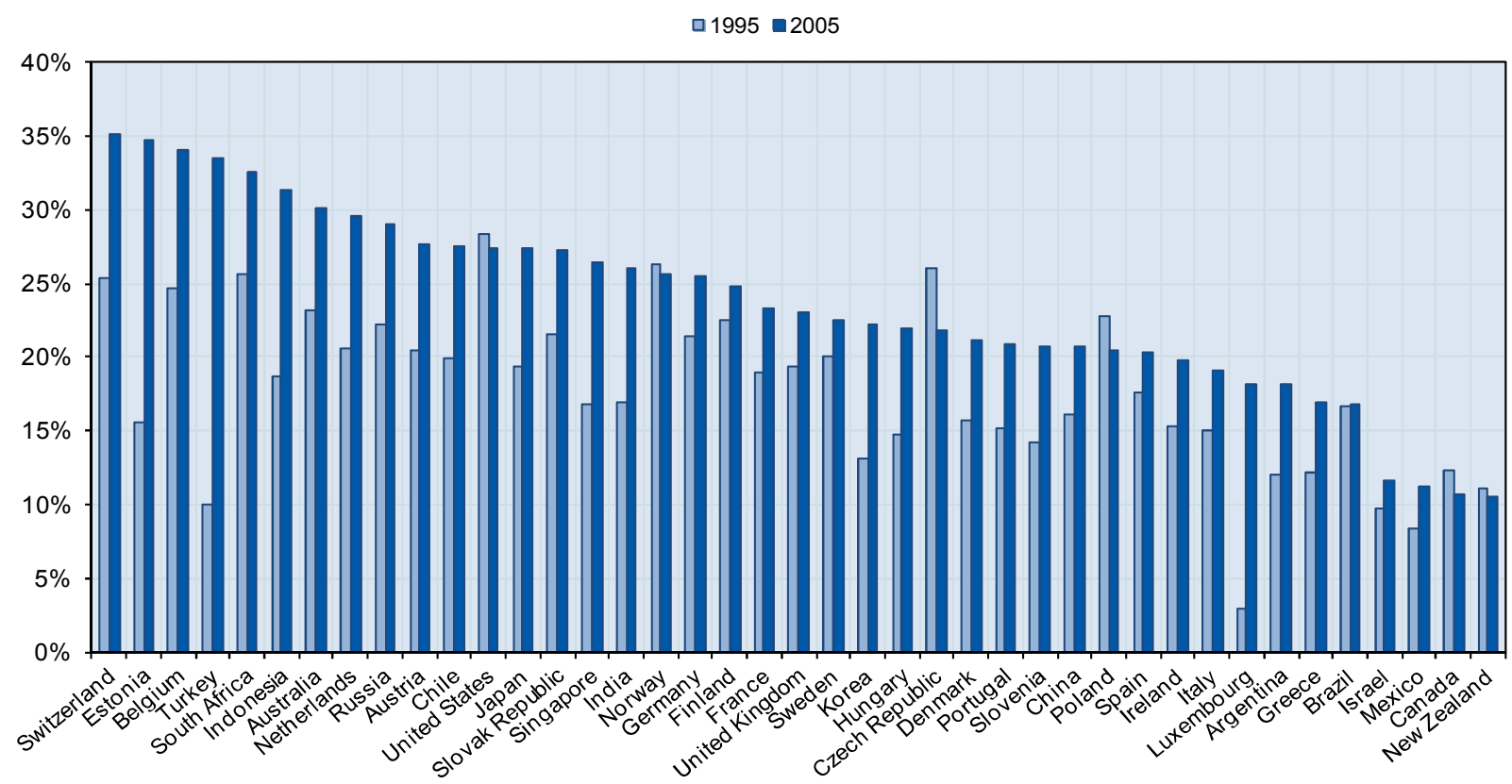

Note: The statistical data for Israel are supplied by and under the responsibility of the relevant Israeli authorities. The use of such data by the OECD is without prejudice to the status of the Golan Heights, East Jerusalem and Israeli settlements in the West Bank under the terms of international law.

Source: Calculations based on OECD I/O tables

\section{Economic linkages between countries: linking IO data with trade data}

By linking I/O tables with bilateral trade data, more insights on the origin and destination of imported intermediates can be gained and the specific linkages between individual countries can be assessed. The distribution of the vertical specialisation measure VS1 by partner countries/zones suggests a strong 'regional' character of GVCs (Figure 13). Countries source intermediates and incorporate them in their exports to a larger degree from neighbouring countries which is likely related to the importance of distance and trade costs for vertical trade.

The import content of exports of European countries is heavily based on other European countries. In most countries around three quarters of the intermediates embodied in exports are sourced from around Europe. Only Ireland seems to be a bit different with a relatively large sourcing from NAFTA countries; the large presence of especially US multinational companies is likely to explain this observation.

Within the NAFTA region, Canada and Mexico are heavily oriented towards the other NAFTA countries: more than $50 \%$ of the imported intermediates embodied in their exports originate in the NAFTA zone. The situation is a bit different for the United States, with a lesser importance of the two other NAFTA countries and a larger share for East Asian countries.

In Asian countries like Japan, China and Korea, the majority of the intermediates embodied in their exports are sourced from within the region. Previous research has shown that a triangular trade pattern has emerged in this region, in which parts and components are produced by more developed countries like Japan, and Korea and then exported to emerging countries like e.g. China and recently increasingly also to other countries like Vietnam and Cambodia where the assembly of the different intermediates into finished products is takes place. The assembled final products and intermediates are then exported back to Japan, 
Korea, etc. as firms re-import a growing part of the production they relocate. Assembled products from China are also exported to other developed countries/regions such as Europe and the United States where they may undergo in addition some smaller changes (packaging, marketing, etc.) and hence appear in the vertical trade of these countries. The case of Apple's iPod illustrates this clearly: components for this product are produced in Japan, Korea and the United States, are then assembled in China and then exported to the United States (Linden et al., 2009).

Figure 13 Vertical specialisation (import content of exports) VS1 with partner countries

\section{European countries}

-From Europe $\quad$ FFrom NAFTA $\quad$ FFrom East Asia $\quad$ FFrom Other Asia $\quad$-From RoW

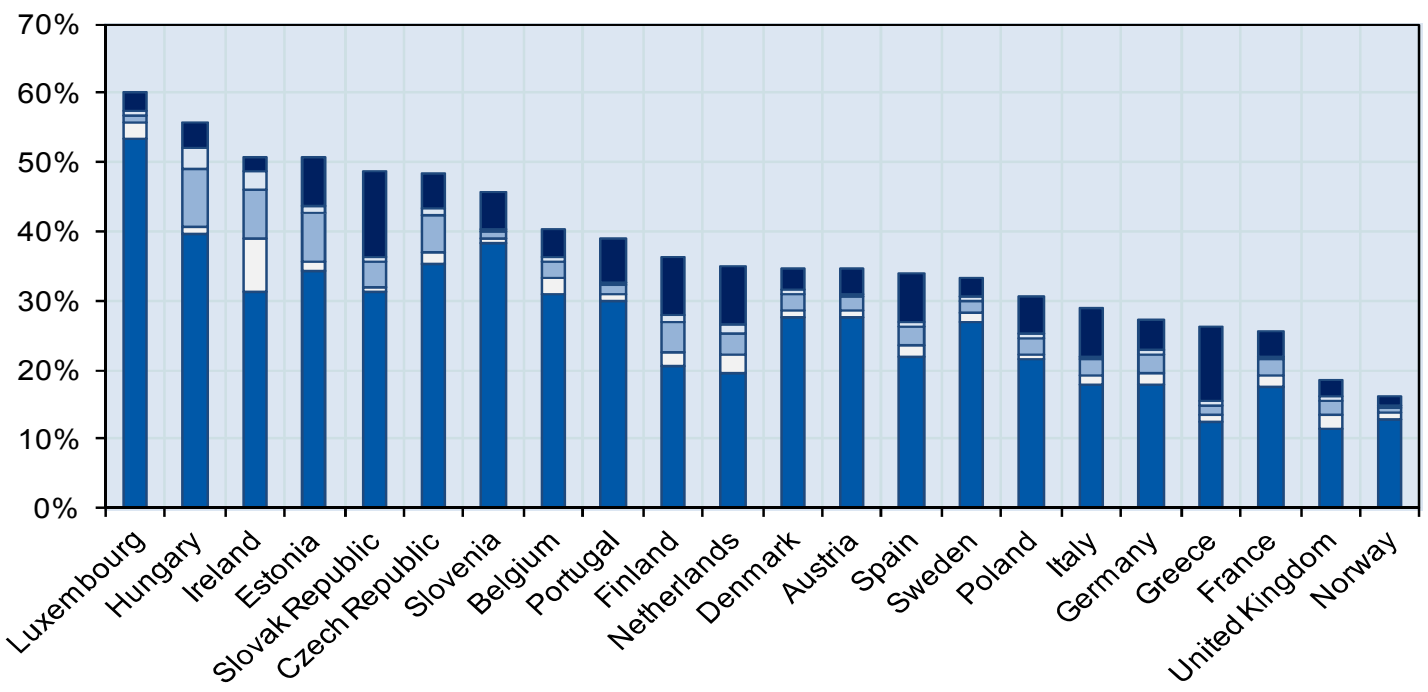

Other countries

-From Europe $\quad$ From NAFTA $\quad$ FFrom East Asia $\quad \square$ From Other Asia $\quad$ From RoW

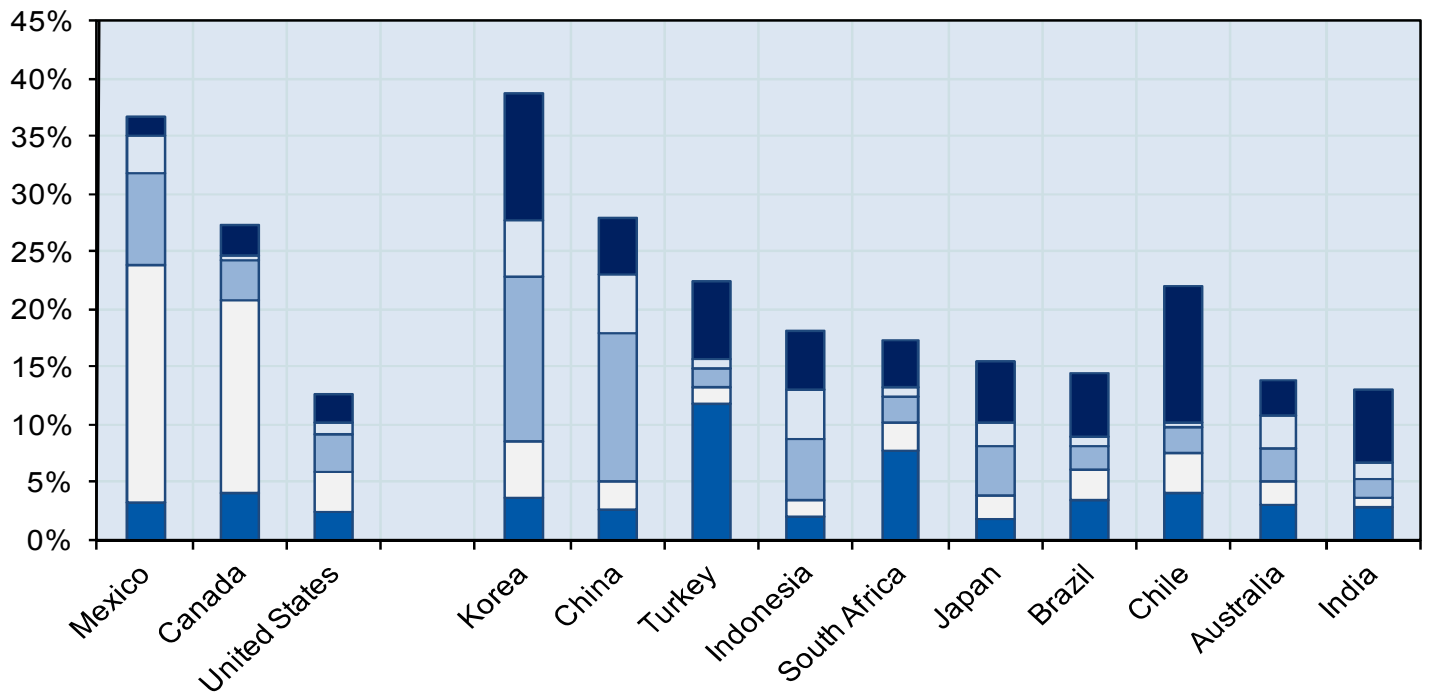

Source: OECD (2010). 
The regional character of GVCs is also clearly illustrated when identifying so-called 'dominant' links of intermediate trade flows between economies. Figure 14 presents the (bilateral) exports of intermediates which represent more than $15 \%$ and $20 \%$ of the total exports of the (exporting) country. The results suggest the existence of 3 large groups of economies in the global trade of intermediate products: NAFTA, EU and Asia including East Asia (with Japan, Korea and China) and ASEAN economies. A large number of dominant links are identified within these groups of economies, while export flows between individual economies across different regional groups are significantly less important. It is merely by aggregating exports of different economies within regional groupings that dominants between NAFTA, EU, East Asia and ASEAN appear.

There are some exceptions like e.g. the exports from Ireland to the United States which is most likely to be related to the large presence of US MNEs in Ireland. A stronger integration is also observed within Asia between East Asian and ASEAN economies and of Asia with other regional blocs. Yamano et al. (2010) showed how the production networks between Asian economies has become much more integrated over the period 1995-2005 and how intermediates are largely exchanged between economies.

The United States have become less centrally, as Annex 1 shows a similar graph of dominant links in intermediates exports for the year 1995. The graph clearly shows how GVCs have significantly changed over a period of 10 years: while in 1995 Japan, Germany and the United States were by far the most important production centres, the increasing spread of GVCs across a larger number of economies shows the stronger integration and hence larger economic dependency of economies. 
DSTI/DOC(2012)3

Figure 14 Dominant links between economies, exports of intermediates, 2005

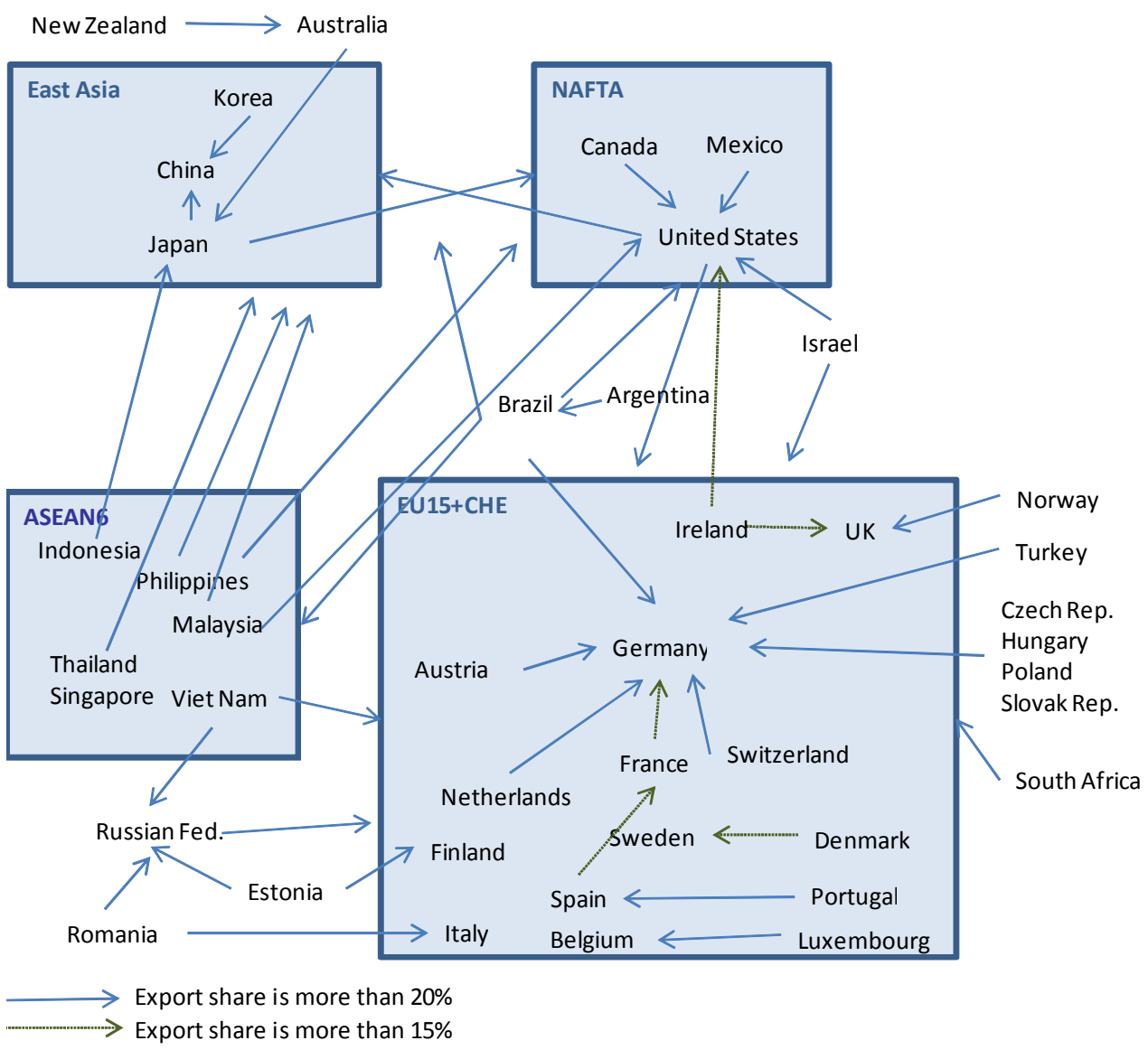

Source: Own calculations based on OECD Input-Output Database (September, 2010) and OECD STAN BTD (March, 2010).

\section{Conclusion: the need for better policy evidence}

Policy makers show an increasing interest in GVCs because of the pervasive effects GVCs have on national economies and are especially looking for more and better policy evidence. As GVCs extend from production over logistics and marketing to $R \& D$ and innovation activities, several policy domains (trade, competitiveness, industrial policy, R\&D and innovation, etc.) will be influenced by the new international organisation of productive activities. Globalisation in general and GVCs in particular are expected to result in a more efficient allocation of productive resources across the world.

The review of the available data and indicators on GVCs in this paper overall shows the increasing importance of GVCs in today's global economy, but at the same time clearly highlights some major shortcomings. While the empirical evidence based on trade data is less convincing, Input-Output data clearly reveal the growing spread of international production networks. Indicators on imported intermediates, offshoring and vertical specialisation all illustrate the growing fragmentation of production across more economies. Trade data seem to show the increasing importance of GVCs only in an indirect way but the existing trade data are not detailed enough and are not collected on the right level of analysis to analyse the international fragmentation and GVCs. 
Further on, while descriptive in character, the existing data and indicators fall short of capturing the impact of GVCs on the competitiveness of countries. New and more intense competition directly affects the international competitiveness of countries and forces governments to analyse carefully in which activities and industries they can keep/gain their comparative advantage. The growing flows of intermediate inputs have increased the economic interdependency between economies but have also contributed to changing patterns of international competitiveness of countries. The international fragmentation allows/forces countries to specialise in different activities in the production process (production of intermediates, final assembly, etc.), in addition to their traditional specialisation in products and industries.

The international performance of countries is often compared using export market shares and indicators of revealed comparative advantage (see e.g. The European Competitiveness Report, 2008). ${ }^{12}$ GVCs directly challenge these 'export' measures of competitiveness as countries' exports are increasingly made up of imports of intermediates inputs from abroad and indicators based solely on export data of final goods might misrepresent the real specialisation of countries. A favourable export-based indicator does not necessarily indicate a competitive edge in the production of a specific good and might hide the fact that a country is merely specialised in the final assembly of that good by importing intermediate inputs while adding/creating less or no value to the good itself.

Koopman et al. (2008) showed that the share of foreign value added in Chinese manufactured exports is about $50 \%$. Looking specifically at processing exports which benefit from duty exemptions on imported raw material and other inputs 'as long they are used solely for export purposes', this foreign share rises up to $82 \%$. As a direct corollary of this, GVCs might also qualify the large trade (bilateral) imbalances between countries. For example, Kierzkowski and Chen (2010) have shown that taking into account the imports of parts and components by both countries reduced the large US deficit with China by approximately half, given that a lot of high value intermediates are exported from the United States to China.

A micro-economic analysis of the international value chain of the iPod has clearly demonstrated the discrepancy between trade performance and value creation across countries (Linden et al., 2009). Using firm-level information, the analysis showed that China was merely specialised in the assembly of the imported intermediates into the final product which is typically generating relatively little value. The largest part of the value creation throughout the production process was done and captured by the producers of high value components (United States and Japan) and the seller of the iPod (Apple in the United States). The iPod example shows that the concept of competitiveness may sometimes need to be assessed at a detailed level, in order to fully understand what drives the international performance of countries.

The OECD is developing new empirical evidence studying the emergence of GVCs based on international trade data and Input-Output data. In addition, the OECD is currently cooperating with other international agencies and academic experts to develop new metrics for GVCs, for example data on trade in value added. One of the main shortcomings of international trade data is that they are expressed in output terms and hence include the value of intermediates imported at each border crossing As such, international trade data suffer from a 'double-counting' problem and tend to overstate the implicit value or factor content exchanged between countries. Trade in value added aim to capture only the domestic content/value that countries are adding to goods and services and will give a better picture of the integration of countries in GVCs.

12 Empirical measures of comparative advantage go back to the seminal work of Balassa (1965): comparative advantage is expected to determine the structure of exports, hence the construction of export performance indices to 'reveal' the comparative advantage of countries. 


\section{ANNEX 1. DOMINANT LINKS BETWEEN ECONOMIES, EXPORTS OF INTERMEDIATES, 1995}

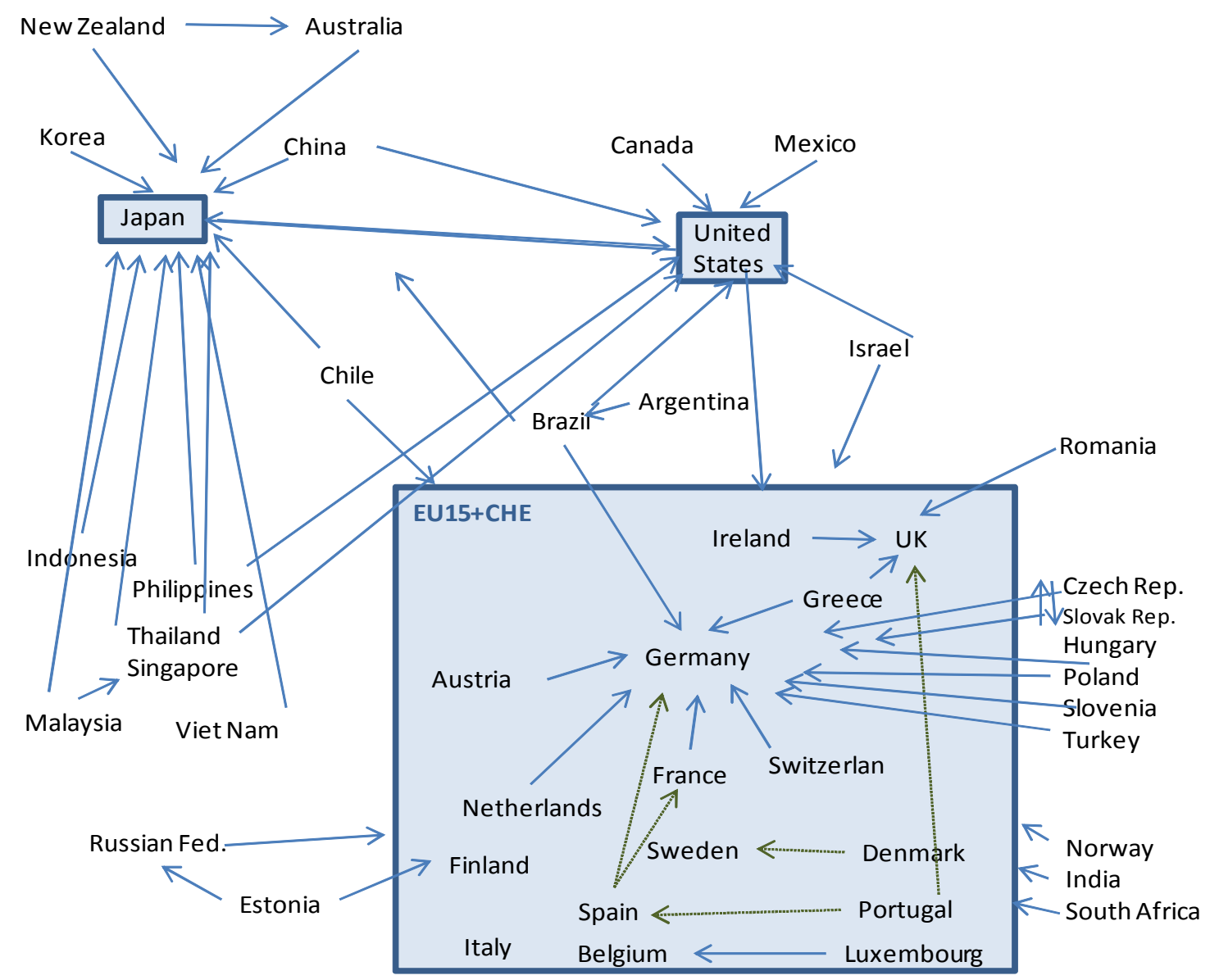

$\rightarrow$ Export share is more than $20 \%$

$\rightarrow$ Export share is more than $15 \%$

Source: Own calculations based on OECD Input-Output Database (September, 2010) and OECD STAN BTD (March, 2010). 


\section{REFERENCES}

Ando, M. (2006), Fragmentation and Vertical Intra-Industry Trade in East Asia, North American Journal of Economics and Finance, Vol. 17, pp. 257-281.

Baldwin, 2006: Globalisation: the Great Unbundling(s), paper prepared for Economic Council of Finland, 2006.

Brulhart, M. (2008), An Account of Inter-Industry Trade, 1962-2006, Research Paper Series in Globalisation, Productivity and Technology, Leverhulme Centre for Research on Globalisation and Economic Policy, University of Nottingham.

Chen, H., M. Kondratowicz and K.-M. Yi (2005), Vertical Specialisation and Three Facts About U.S. International Trade, North American Journal of Economics and Finance, Vol. 16, pp. 35-39.

De Backer and Yamano (2007), The Measurement of Globalisation Using International Input-Output Tables, OECD STI Working Paper, No. 2007/8.

Dixit, A.K. and J.E. Stiglitz (1977), Monopolistic Competition and Optimum Product Diversity, American Economic Review, Vol. 67, pp. 297-308.

Dixit, A.K. and G.M. Grossman (1982), Trade and Protection with Multistage Production, Review of Economic Studies, Vol. 49, No. 4, pp. 583-594.

European Commission (2008), European Competitiveness Report 2008, Brussels.

Falvey, R.E. (1981), Commercial Policy and Intra-Industry Trade, Journal of International Economics, Vol. 11, pp. 95-115.

Fontagné, L., M. Freudenberg and G. Gaulier (2006), A Systematic Decomposition of World Trade, Review of World Economics, Vol. 142, No. 3, pp. 459-475.

Gereffi, G., J. Humphrey and T. Sturgeon (2005), The Governance of Global Value Chains, Review of International Political Economy, Vol. 12, No. 1, pp. 78-104.

Grossman and Rossi-Hansberg (2006) Trading Tasks: A Simple Theory of Offshoring, NBER Working Papers 12721, National Bureau of Economic Research.

Hummels, David \& Ishii, Jun \& Yi, Kei-Mu (2001) The nature and growth of vertical specialization in world trade, Journal of International Economics, Elsevier, vol. 54(1), pages 75-96, June.

Jones, R.W. and H. Kierskowski (1990), The Role of Services in Production and International Trade: A Theoretical Framework in R.W. Jones \& A.O. Krueger (Eds), The Political Economy of International Trade: Essays in Honour of R.E. Baldwin, Oxford.

Kierzkowski, H. and L. Chen (2010), Outsourcing and Trade Imbalances: The United States - China Case, Pacific Economic Review, Vol. 15, No. 1, pp. 56-70. 
Koopman, R., Z. Wang and S.-J. Wei (2008), How Much of Chinese Exports is Really Made in China? Assessing Domestic Value-Added When Processing Trade Is Pervasive, NBER Working Paper Series, No. 14109, Cambridge, MA.

Krugman, P.R. (1979), Increasing Returns, Monopolistic Competition and International Trade, Journal of International Economics, Vol. 9, pp. 469-479.

Lancaster, L. (1979), Variety, Equity and Efficiency, Columbia University Press, New York.

Linden, G., K.L. Kraemer and J. Dedrick (2009), Who Captures value in a Global Innovation Network? The Case of Apple's iPod, Communications of the ACM, Vol. 52, No.3, pp. 140-144.

Miroudot, S., R. Lanz and A. Ragoussis (2009), Trade in Intermediate Goods and. Services, OECD Trade Policy Working Papers, No. 93.

Spence, M.A. (1976), Product Differentiation and Welfare, American Economic Review, Vol. 66, pp. 407-414.

OECD (2007), Staying competitive in a global economy: Moving up the Value Chain, Paris.

OECD (2010), Economic Globalisation Indicators 2010, Paris.

Sturgeon, T. (2002) Modular Production Networks: a New American Model of Industrial organisation, Industrial and Corporate Change, Vol. 11, No. 3, pp. 451-496.

Sturgeon T. and G. Gereffi (2009), Measuring Success in the Global Economy: International Trade, Industrial Upgrading, and Business Function Outsourcing in Global Value Chains, Transitional Corporations, Vol. 18, no. 2, pp. 1-36.

Sturgeon T. and O. Memedovic (2010), Measuring Global Value Chains: Intermediate Goods Trade, Structural Change and Compressed Development, UNIDO Working Paper, Vienna.

Türkcan, K. (2010), Vertical Intra-Industry Trade and Product Fragmentation in the Auto-Parts Industry, Journal of Industry, Competition and Trade, published on-line.

Uchida, Y. and S. Inomata (2009), Vertical Specialisation at the Time of Economic Crisis, in S. Inomata \& Y. Uchida (Eds) Asia Beyond the Crisis: Visions from International Input-Output Analysis, IDEJETRO, Chiba, Japan.

United States Government Accountability Office (2005), "Offshoring of Services: An Overview of the Issues", GAO-06-05.

Van Welsum, D. and G. Vickery (2004), Potential offshoring of ICT-intensive using occupations, DSTI/ICCP/IE(2004)19/FINAL, OECD, Paris.

Winkler, D. and W. Milberg (2009), Errors from the 'Proportionality Assumption' in the Measurement of Offshoring: Application to Germany's Labour Demand, SCEPA Working Paper Series, No. 2009-12, Schwartz Centre for Economic Policy Analysis, The New School, NY.

Yamano, N., B. Meng and K. Fukasaku (2010), Fragmentation and Changes in the Asian Trade Network, ERIA Research Brief, Economic Research Institute for ASEAN and East Asia. 
DSTI/DOC(2012)3

Yeats, A. (1997), Just How Big Is Global Production Sharing?, World Bank Policy Research Paper No. 1871, Washington.

Yi, K.-M. (2003), Can Vertical Specialization Explain the Growth of World Trade?, Journal of Political Economy, Vol. 111, No. 1, pp. 52-102. 